\title{
Learning to encode possession
}

\author{
Sonja Eisenbeiß, Ayumi Matsuo and Ingrid \\ Sonnenstuhl
}

\section{Introduction}

Learning and talking about their own possessions and the possessions of their peers and caretakers plays a central role in children's daily life. It is unsurprising then that relationships between possessors and their possessions are amongst the first relationships that children encode when they start to string words together (see e.g. Brown 1973); and it is no wonder that many psycholinguists have made use of this rich data source to address questions about the mechanisms that drive children's linguistic development.

However, most of the available studies of the acquisition of possessive constructions that we will discuss have investigated only one or two possession-encoding constructions in an individual language. Moreover, the focus has typically not been on the encoding of the possessive relation itself, but on other aspects of the respective possessive construction. For instance, possessive $-s$ markers in German and English (e.g. Susi-s Huhn 'Sue's chicken') were analysed in studies that investigated whether the syntactic categories of the target language were already present in early child grammars (e.g. Eisenbeiß 2000; Marinis 2002, 2003; Radford 1990). In these studies, possessive markers were simply treated as morpho-syntactic realisations of syntactic categories; and semantic aspects were largely ignored. Similarly, possessive constructions with two-place verbs like have and belong were investigated in studies of the acquisition of syntax-semantic mappings, but these constructions were just treated as one type of twoargument construction and not compared to other constructions encoding possession (see e.g. Bowerman 1990 , Pinker 1984). To our knowledge, no study has yet provided a comprehensive cross-linguistic overview that focuses on the different ways in which possessive relationships are encoded linguistically.

In order to fill this gap, we will provide a cross-linguistic overview of studies of children's acquisition of the constructions that their target language employs to encode possession. In addition, we will present new data from German child language and child-directed speech, and discuss the im- 
plications for theoretical linguistics and language acquisition research. Our focus will be on three ways of encoding relationships between PRs and possessed entities (see Heine 1997; Baron, Herslund and Sørensen 2001 for overviews):

- adnominal possession: Both Possessor (PR) and Possessum (PM) are encoded within the same noun phrase (e.g. my/daddy's chickens, the chickens of our neighbours, ...);

- predicative possession: The possessive relationship is encoded by a twoplace predicate such as have, own or belong or by be (e.g. I have a dog. The dog belongs to me. This dog is mine);

- "external possession": the PR and the PM are realised as arguments of a verb whose lexical meaning does not involve the notion of possession (e.g. I tapped him- $P R$ on the shoulder- $P M$ ).

We will first show how studies of children's possession constructions can help us to evaluate models of children's linguistic development. Against this background, we will present studies of the acquisition of adnominal, predicative and external possession constructions (EPCs). For each of these construction types, we will provide a brief overview of possession constructions in adult German and contrast them with possessive constructions in other languages for which acquisition studies are available. This will allow us to discuss empirical findings from earlier studies and our own analysis of German child data. Finally, we will compare the development of the three types of possession constructions and discuss the implications of our findings for theoretical linguistics and models of children's linguistic development. In particular, we will show how the available empirical findings about the acquisition of possession constructions can be captured in approaches that try to integrate core insights from current generative and usage-based approaches.

\section{Theoretical issues in acquisition research}

While concepts of ownership and possession seem to be part of all cultures, there is considerable variation with respect to (i) the legal norms for establishing, maintaining and negotiating ownership and (ii) the linguistic means to encode ownership and other types of possessive relationships. Hence, when they learn to talk about ownership and possession children have to acquire both cultural and linguistic knowledge. In this study, we will focus 
on linguistic aspects, i.e., we will investigate how children acquire the possessive constructions of their target languages - and what this can tell us about the mechanisms that drive children's linguistic development.

Current research on the mechanisms underlying children's language acquisition is characterised by an opposition between generative approaches (see Eisenbeiß 2009 for overview) and functionalist or usage-based approaches (Bates and MacWhinney 1987; Tomasello 2003, 2006; Goldberg 2006). Moreover, acquisition researchers have provided competing accounts for the time course of linguistic development and for the orders in which children acquire the properties of their target language. In the following, we will first provide an overview of these debates before we present data on the acquisition of possession constructions that can help us evaluate competing models.

\subsection{The logical problem of language acquisition}

The opposition between generative and usage-based accounts of language acquisition arose from discussions about the so-called "logical problem of language acquisition" (Baker 1979; Bertolo 2001; Pinker 1989, and the special issue of The Linguistic Review 19, 1-2). Children only hear a limited sample of their target language, and hence have to generalise over individual input utterances in order to comprehend and produce new utterances. If children's hypothesis space for these generalisations were completely unconstrained, children might make incorrect generalizations and one would have to explain how they would ultimately reject them. For example, German children frequently hear the possessive marker $-s$ on nouns that encode PRs (e.g. Susi-s Huhn 'Susi's chicken', Oma-s Haus 'granny's house'). This might lead them to use this marker with any PR noun or noun phrase. However, this would not be the appropriate generalisation for German: $-s$ can only be affixed to proper names like Susi and a few kinship terms such as Mama 'mommy' that can function as proper names (see Harbert 2007: $161 \mathrm{ff}$. and the discussion below). Moreover, even with this restricted set of nouns, $-s$ cannot appear when the noun is modified, e.g. by a determiner or possessive pronoun (*meine Mamas Huhn 'my mommy's chicken'). As we will show below German children do not always restrict the use of $-s$ to unmodified proper names and kinship terms, but overgeneralise it to unmodified count nouns such as Affe 'monkey', which cannot be combined with $-s$ in the target language (Mills 1985; Eisenbeiß 2000). Thus, one has to explain why children produce such non-target-like combinations, how 
they overcome these "errors", and how they learn to use morpho-syntactic forms appropriately.

One could argue that children "unlearn" errors on the basis of negative evidence, i.e. information about the ungrammaticality of their utterances. However, many studies have shown that explicit corrections are not systematically available to all children at all developmental stages (Marcus 1993). Moreover, even for explicit corrections such as You can't say that, it is not obvious whether the correction refers to the phonological or morphosyntactic structure, the use of lexical elements, or the appropriateness of the utterance in the social context. In addition, children do not always take up corrections - and even if they do seem to take them up, they might later go back to their non-target like structures; see Marcus (1993) for an overview and the following example from Simone Miller $\left(2 ; 4,{ }^{1}\right.$ see Miller 1976; Eisenbeiß 2003: 45): ${ }^{2}$

(1) Father: Wem gehört der Löffel?

whom-DAT belongs the-NOM spoon?

'To whom does the spoon belong?'

Simone: Ich. (correct: Mir)

I-NOM (correct: me-DAT)

'I' (correct: 'to me')

Father: Wem gehört der Löffel?

whom-DAT belongs the-NOM spoon?

'To whom does the spoon belong?'

Simone: Ich. Ja.

I-NOM. Yes

'I' (correct: 'to me')

1 Age information is provided in the following format: Year; Month.

2 We have used the following abbreviations and glosses: [\#] - pause; [/] - interruption; ACC - accusative; DAT - dative; D-elements - case/gender/numbermarked articles, possessive pronouns, demonstratives, quantifiers; EPC - external possession construction (I hit him on the head); FEM-feminine; GEN-genitive; IPC - internal possession construction (I hit his head); MASC - masculine; NEUT - neuter; NOM - nominative; PART - particle (note that as it is difficult to provide exact translations for German focus and other particles, particles will simply be glossed as PART, without further information); PM-Possesssum; PR Possessor; SG - singular; and TAG - tag question. 
Father: Wem gehört der Löffel?

whom-DAT belongs the-NOM spoon?

'To whom does the spoon belong?'

Simone: Ich.

I-NOM

'I' (correct: 'to me')

Father: Mir. Wem gehört der Löffel?

me-DAT. Whom-DAT belongs the-NOM spoon?

'To me. To whom does the spoon belong?'

Simone: Mir.

me-DAT

'To me'

Father: Wem gehört der Löffel?

whom-DAT belongs the-NOM spoon?

'To whom does the spoon belong?'

Simone: Mir.

me-DAT

'To me'

Father: Mir. Und das bist Du. ne? me-DAT. And that is you. TAG?

Simone: Ja. Gehört mir. [...] yes. belongs me-DAT

Father: Wem gehört der Löffel?

whom-DAT belongs the-NOM spoon?

'To whom does the spoon belong?'

Simone: Ich.

I-NOM.

'I' (correct: 'to me')

Other types of negative evidence do not seem to provide sufficient substitutes for explicit corrections: indirect negative evidence, i.e. the lack of a particular form or construction in the input, might be informative, but taken on its own, it is not reliable enough. There are many types of structures that children are never exposed to (e.g. sentences with long extractions), but are still not considered ungrammatical by adults. This suggests that children do not simply stop adding possessive $-s$ to common nouns like Affe 'monkey' because they never hear possessive constructions like that. Some acquisition researchers have argued that certain types of parental responses - e.g. 
repetitions with reformulations - occur more frequently after errors than after correct utterances (see Marcus 1993; Cowie 1999 for references and discussion). However, even such "noisy" negative evidence is not provided systematically enough and it is not clear how exactly children could make use of it (Marcus 1993). Hence, acquisition researchers have to explain how children can generalise beyond individual input utterances, but recover from non-target-like generalisations even though they cannot rely on explicit, indirect or noisy negative evidence.

Faced with this "logical problem of language acquisition", generative linguists have postulated that children's language acquisition is guided by innate well-formedness constraints that apply to all grammatical structures of human languages. These innate constraints are assumed to restrict children's hypothesis space so that they can only make target-like generalizations or generalizations that can be rejected without explicit correction. In the early days of generative grammar, the universal well-formedness constraints were formulated as domain-specific principles; i.e. they were considered to be specifically targeted to the domain of language (Chomsky $1965,1981)$. Thus, the child's language acquisition mechanism was viewed as a domain-specific mechanism that cannot be derived from other cognitive or social skills.

Recently, generative linguists in the minimalist framework (e.g. Chomsky 1995, 2001) have started to derive the domain-specific principles of early generative grammar from more general cognitive principles, for instance, economy principles according to which grammatical operations (e.g. movement) are only allowed if they are required to fulfill other wellformedness constraints (see Chomsky 1995, 2001; Eisenbeiß 2003, 2009 for overviews). This shows some convergence with the functionalist or usage-based approaches to language acquisition, which assume that general cognitive and socio-pragmatic principles suffice to constrain children's hypothesis space because children's input provides rich, structured information about the target language (see e.g. Bates and MacWhinney 1987; Tomasello 2003, 2006).

In particular, most generative and usage-based approaches to human languages and their acquisition now assume some version of the Specificity Principle, a general principle that requires operations with more specific outputs or inputs to have precedence over operations with less specific outputs or inputs (see Eisenbeiß 2003, 2009 for discussion). This principle has been formulated as a domain-specific Elsewhere Principle (Kiparsky 1982) or Blocking Mechanism (Marcus et al. 1992) and as a pragmatically based general Principle of Contrast (Clark 1987); and the function of the Specificity Principle has been investigated in connectionist simulations (Corina 
1994). Whatever its precise formulation, such a general Specificity Principle can, for instance, explain why an adult who has acquired the specific irregular past tense form went would not use overgeneralised forms like *go-ed: the presence of the specific irregular form would block or pre-empt the application of the general past tense -ed-affixation.

Moreover, acquisition researchers have suggested that a Specificity Principle could help children overcome morphological overgeneralisations such as the overgeneralisation of the plural $-s$ to irregularly inflected nouns (e.g. *mouses instead of mice; see e.g. Bates and MacWhinney 1987; Braine and Brooks 1995; Clark 1987; Eisenbeiß 2003, 2009; Marcus et al., 1992; Tomasello 2003, 2006). For such morphological overgeneralisations, where a specific form is competing with an overgeneralised form, any use of the appropriate specific adult form in the child's input could provide a competitor for the child's non-target-like general form - and thus lead to the child abandoning the non-target-like overgeneralised form.

Recognising adult morphological forms and their contrast to the nontarget-like forms is supported by several characteristic properties of children's input. In particular, cross-linguistic and cross-cultural studies have shown that child-directed speech is rich in so-called "variation sets", i.e. sequences of utterances with a constant communicative intention, but minimal variations in word order, lexical choice or inflectional form (Eisenbeiß 2003; Küntay and Slobin 1996, 2002; Slobin et al. submitted). For instance, the variation set in (2a) contains both the singular and the plural form of mouse, which highlights these forms and the paradigmatic contrast between them. In this way, variation sets with appropriate adult forms might make competitors for the child's non-target-like forms more salient and support their acquisition.

Other properties of child-directed speech that highlight contrasts between adult and non-target-like child forms are reformulations such as (2b), where the adult form is directly contrasted with the child's incorrect form. Such reformulations seem to be frequent in Western cultures, but it is not clear whether they are common across the world (see Chouinard and Clark 2003 for discussion). Nevertheless, where they occur, reformulations might offer additional support for children's acquisition of morphological forms.

(2) a. Look there are so many mice in this picture: There is one mouse under the table and one mouse under the chair and two mice under the bed and three mice in the corner.

b. Child:There are the two mouses again!

Adult:Yes, we have seen these two mice before. 
Note, however, that reformulations do not necessarily indicate that the child's utterance is incorrect. For instance, if children use $m y$ to refer to their own possession and the parent replies using your, this should not be taken as a correction of the child's use of $m y$, which was appropriate, but spoken from a different perspective than the mother's utterance.

Thus, in sum, any use of the appropriate adult form that occurs in the child's input could provide a competitor for a child's overgeneralised inflected form. In addition, variation sets or reformulations might highlight these competitors and their contrast to the non-target-like form and thus provide further support. Appendix A provides a transcript from a German family that shows how a short everyday conversation can provide children with many models and contrasts for adnominal possessive constructions (A1, A2, A10, A11, A12, A14, A16), predicative possessive constructions (A18, A20, A21) and EPCs (A22, A23). However, more work on the role of contrasts in the child's input is needed.

Note, however, that the mechanisms that might help children to drop overgeneralisations such as *mouses from their language cannot help them to overcome overgeneralisations of German possessive $-s$ to common nouns such as Affe 'monkey': in contrast to the domain of morphology, the domain of syntax allows more variation. For instance, in adult German, there are several alternative adnominal possessive constructions: the possessive $-s$ construction (Mama-s Huhn 'mommy's chicken'), the prepositional construction (das Huhn von der Mama [the chicken of the mommy] 'mommy's chicken') and the rather formal and much rarer genitive construction (das Huhn der/meiner ${ }_{\mathrm{GEN}}$ Mama [the chicken the/my-GEN mommy] 'the/my mommy's chicken'). Thus, when children hear prepositional possessive constructions like das Huhn von der Mama, they should not stop using Mamas Huhn 'Mommy's chicken' as this $-s$ possessive is actually correct in adult German. Consequently, hearing die Banane von dem Affen 'the banana of the monkey' should not directly drive out an error like *Affes Banane 'monkey's banana'. Thus, we will have to determine how children can learn how to use alternative possessive constructions and handle the constraints for their use in the target language.

At the same time, we will have to explain why some errors appear in children's data, while other potential errors have not been observed. For instance, we will show that though German children overgeneralise $-s$ to unmodified common nouns that are incompatible with this marker, children do not seem to overgeneralise $-s$ to full phrasal PRs (e.g. *meine Mamas Huhn 'my mother's chicken'). This requires an explanation as $-s$ overgeneralisations are documented in German child language and phrasal possessive 
markers are not uncommon in natural languages - what is more, they occur in English, which has adnominal possessive constructions that are otherwise very similar to the corresponding German constructions.

Thus, when we discuss the acquisition of possessive constructions in the following sections, we will address the logical problem and explain how children manage to avoid or overcome deviations from the target language without recourse to reliable negative evidence. In addition, we also have to capture the time-course of children's linguistic development, i.e. explain why children acquire particular properties of their target language at a particular time and in a particular order.

\subsection{The time-course of linguistic development}

Most acquisition researchers today, whether they subscribe to a generative or a functionalist view, agree that the mechanisms that drive language acquisition do not change qualitatively over time (see e.g. Pinker 1984; Eisenbeiß 2009; Tomasello 2003 for overviews and discussion). Moreover, there seems to be an emerging consensus that children acquire the most basic

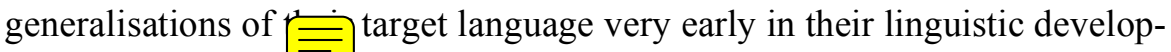
ment (Guasti 200z, 7 Iomasello 2006). This has for instance been shown for the basic word order patterns or the ways in which motion events are encoded (see e.g. Slobin et al. submitted). The early adaptation to the target language can be captured in generative and in functionalist approaches alike, though the explanations differ: generative authors highlight the role of innate constraints (e.g. Crain 1991), others point out children's powerful predispositions for pattern detection and analogy formation (e.g. Tomasello 2006), while others refer to "helpful" input properties such as variation sets (Slobin et al. submitted). Thus, if our investigations should show early adaptations to the target language for the domain of possession constructions, this would be compatible with a broad range of theoretical approaches to language acquisition and provide further evidence for them.

In addition, investigating children's "errors" in the acquisition of possession constructions can contribute to the ongoing debate about children's grammatical representations at different stages of development. Proponents of generative Full-Competence approaches claim that children's morphosyntactic representations are adult-like as soon as they start to combine words (e.g. Hyams 1996; Lust 1994; Rizzi 1993/1994, 2000; Wexler 1998). Thus, they cannot view omissions of possessive markers or other deviations from the target language as results of non-adult grammatical representations. 
Rather, any deviations from the target must be attributed to other factors; and Full-Competence proponents have suggested a number of such factors, e.g. the late maturation of general cognitive constraints, problems with the morphological or phonological realization of unstressed morphemes and underdeveloped pragmatic knowledge (see Guasti 2002; Eisenbeiß 2009 for overviews).

In contrast to such Full-Competence approaches, Structure-Building approaches do not assume adult-like representations for the early two-word stage. Hence, they must account for children's early grammatical representations and explain how children acquire adult-like representations. Most current Structure-Building approaches adopt versions of the Lexical Learning Hypothesis (see Pinker 1984; Eisenbeiß 2007, 2009 for overviews; see Radford 1990 for an earlier maturational approach). According to this hypothesis, children have adult-like categorisation abilities, but they still need to determine the grammatical features and properties of the input elements they encounter. Recent versions of Lexical-Learning approaches assume that this process is incremental: grammatical distinctions are acquired one by one, lexeme by lexeme, and with initial restrictions of inflections to individual lexemes that frequently appear with these markers in the input (see e.g. Eisenbeiß 2003, 2007). For instance, possessive markers should initially be restricted to individual words - and only later generalised to all words or phrases that can carry this marker in the target language (Eisenbeiß 2000).

Usage-based approaches make similar predictions as Lexical-Learning approaches, though on the basis of slightly different assumptions. According to them, adults grammars are based on schemas or constructions, i.e. interrelated form/meaning pairs that are characterized by various degrees of abstractness, ranging from idioms with concrete lexical items (e.g. kick the bucket 'die'), to abstract templates characterized by grammatical roles such as subject-predicate (e.g. Goldberg 1995, 2006). Children are assumed to acquire such templates step by step; beginning with limited generalisations that are centred on individual words or phrases and then gradually extending these generalizations by analogy. For instance, Tomasello $(2003,2006)$ argues that grammatical morphemes such as case markers and agreement markers are initially associated with individual (high frequency) verbs. Only when a critical mass of such "verb-islands" is learned do children acquire more general constructions, e.g. the transitive construction.

Thus, taken together, both generative and usage-based approaches predict that children acquire the general properties of the possessive constructions that they hear in their input already in the two-word stage. Moreover, structure-building approaches as well as usage-based approaches specifi- 
cally predict an incremental acquisition of the specific properties of individual possessive constructions and markers, with initial lexical restrictions of possessive markers. By contrast, capturing such a developmental path would require additional assumptions in a full-competence approach, for instance, reference to the interaction between linguistic development and the learning of cultural norms for possessive relations and negotiations about them.

With respect to the order in which linguistic constructions are acquired, most current approaches to language acquisition only make very general predictions that are not directly relevant for the acquisition of possessive constructions. ${ }^{3}$ However, most acquisition researchers agree that conceptual complexity may influence acquisition orders (see Eisenbeiß 2006, 2009 for discussion). In the following, we will discuss several factors that affect conceptual complexity and could thus influence developmental orders: in the section about attributive possession, we will explore the conceptual differences between possessive relations that involve ownership, kinship relations, body-part relations, etc. Here, we will argue that more prototypical types of possession, which involve physical control and proximity (Heine 1997; Seiler 1983) are acquired earlier than more abstract notions of possession.

In the section on predicative possesion, we will discuss the observation that possession constructions have often developed on the basis of older locative constructions that encode a more concrete and "visible" relationship; and we will investigate whether we can observe a similar pattern in children's linguistic development. Moreover, we will study when children start to produce utterances that involve different types of possessive relations, e.g. ownership vs. current physical proximity and control in an utterance like I have my mommy's glasses now.

In the section on external possession, we will investigate EPCs like I hit him on the head and internal possession constructions (IPC) like I hit his head. Both constructions involve an Agent-Patient relation between the hitter and the hittee as well as a possessive relation between the Patient and

3 For instance, Radford (1996) argues that morpho-syntactic realizations of the functional category COMP (complementizers, wh-elements, etc.) are acquired later than realizations of the functional category INFL (tense and agreement inflections, etc.). Moreover, some generative psycholinguists argue that the ability to produce adult-like passive sentences only develops around the fourth birthday, due to neural maturation of the underlying mechanisms (e.g. Borer and Wexler 1987). See Eisenbeiß (2009) and Tomasello (2003) for critical discussion. 
their body part. However, in the EPC, both relations have to be mapped onto a single argument hierarchy as both PR and PM are realised as verb arguments. By contrast, in IPCs, the Agent-Patient relation is realised on the sentential level while the possessive relationship is encoded within the Patient noun phrase. We will argue that this is conceptually simpler than the integration of agentive and possessive relations in the EPC - which should be reflected in acquisition orders and possibly also in deviations from the target language.

\section{The German data}

Our study of German child language is based on 64 recordings from 7 monolingual German children, aged $1 ; 11$ to $3 ; 6$. The data come from the Clahsen corpus (Clahsen 1982), the LEXLERN corpus (see Clahsen, Vainikka, and Young-Scholten 1990) and the Wagner corpus (1985; see Appendix B for details). Some of the LEXLERN recordings involved games in which possessions were compared or exchanged (see Eisenbeiß 1994, 2003). Therefore, they are comparatively rich in possessive constructions and some aspects of possessive constructions have already been studied in these corpora (Eisenbeiß 2000).

In order to analyse the course of development and to create comparable data sets from children at similar stages of development, we assigned the individual recordings to four developmental stages. We did not use chronological age to group the data as age is not considered to be a good indicator of linguistic development. MLU (mean length of utterance) is also not sufficient as some of the later recordings have MLUs of more than 3 words per utterance; and MLU-values in that range are not as indicative of linguistic development as lower values. Thus, we had to find another way of grouping the recordings for comparisons.

Noun-phrase development is obviously crucial for adnominal possession constructions; and the case markers in noun phrases are central for predicative possession constructions and EPCs. Therefore, we decided to group our recordings on the basis of the four-stage model of noun-phrase development that Eisenbeiß $(2000,2003)$ had proposed in her analysis of German child language data and applied to our data set (see Appendix B).

STAGE I

Children frequently omit possessive markers and other morphological markers. They also omit D-elements, i.e. function words in the noun 
phrase (e.g. case/gender/number-marked articles, possessive pronouns, demonstratives, quantifiers). At the same time, the occurrence of Delements is restricted to potentially formulaic combinations with a small set of high-frequency predicates and nouns (e.g. das-is-ein-X 'that-is-a$\mathrm{X}$ ', die-mama 'the mommy').

STAGE II

The percentage of D-elements falls to even lower levels.

STAGE III

The percentage of D-elements increases again. Formulaic utterances become less frequent and children start to combine D-elements more freely with a broader range of predicates and nouns.

STAGE IV

Children typically produce D-elements whenever they are required.

Taken together, this U-shaped development in the provision of function words and the early distributional restrictions for these elements suggest that these elements are initially part of unanalysed chunks that are later reanalysed. Hence, it is crucial not to mix data from the different stages for analysis.

\section{Adnominal possession}

In the following, we will first give an overview of adnominal possession constructions in adult German and contrast them with the corresponding constructions in other languages for which acquisition studies are available English, Japanese, Greek, and Hebrew. Based on this, we will discuss empirical findings from available acquisition studies and our own study.

\subsection{Adnominal possession in the adult language}

In order to illustrate the typological differences with respect to adnominal possession constructions and their implications for language acquisition, we will first look at two closely related languages, namely German and English. In both languages, PRs can either be referred to by pronominal elements as in $(3 a, b)$ or by non-pronominal noun phrases as in $(3 \mathrm{c}-\mathrm{i})$. Moreover, both pronominal and non-pronominal PRs can be combined with a preposition as in $(3 b, d-f)$ or they can appear without it as in $(3 a-c, g-i)$. The prepositional 
PR phrase has to follow the PR in English as in (3b,d), and it tends to appear in the same position in German as in $(3 b, d)$. However, in German, at least some speakers find it acceptable to position the prepositional PR phrase to the left of the PR for emphasis as in (3e) or to extract the prepositional PR phrase in a question - see (3f). Note, however, that structures where the prepositional phrase does not follow the PR are highly marked if not unacceptable.

In addition to the adnominal possession constructions in (3a) to (3f), German has two constructions that do not have an equivalent in English. The first one is a genitive construction, where the PR noun phrase typically follows the PM as in (3g), but may also precede it as in (3h). This genitive construction is more characteristic of formal and written German, has so far not been observed in the speech of pre-school children (Clahsen et al. 1994; Eisenbeiß 2000; Mills 1985), and does not occur in the corpora we analysed. Note that the genitive construction is different from the possessive $-s$ construction though this is not immediately obvious for masculine nouns that take $-s$ as their genitive ending (see $(3 \mathrm{~g}, \mathrm{~h})$ ). The difference between the $-s$ possessive and the "real" genitive can be seen when one looks at masculine nouns with a different genitive ending or femine nouns, which do not carry any overt marker in the genitive (see (3i)).

The second German possessive construction without an English equivalent appears in some spoken variants of German and involves a PM that is preceded by a dative-marked PR and a resumptive possessive pronoun, as in $(3 \mathrm{j})$. Due to its regional character, this construction is rarely discussed in the acquisition literature (see Penner and Weissenborn 1994 for some initial observations), and we only found three instances of this type in the data of the German boy Carsten that we analysed. Therefore, we will not discuss adnominal genitive and dative constructions in a lot of detail.

(3) a. sein Freund

his friend

'his friend'

b. ein Freund von ihm

a friend of his

'a friend of his'

c. Pauls Freund

Paul's friend

'Paul's friend' 
d. ein Freund von Paul/seinem Vater

a friend of $\mathrm{Paul} / \mathrm{his}$ father

'a friend of Paul's' / 'a friend of his father'

e. Das ist bestimmt VON PAUL der Freund

that is surely OF PAUL the friend

'That is surely Paul's friend'

f. Von wem hast du den Vater gesehen?

of whom have you the father seen?

'Whose father have you seen?'

g. ein Freund seines Vaters

a friend his-GEN father's

'a friend of his father'

h. Pauls/seines Vaters Freund

Paul's/his-GEN father's friend

'Paul's friend' / 'his father's friend'

i. eine Freundin meiner Mutter / des Jungen

a friend my-GEN mother's/ the-GEN boy's

'a friend of my mother' / 'a friend of the boy'

j. dem Paul/Vater sein Freund

the-DAT Paul / father his friend

'Paul's friend' / 'the father's friend'

Given the range of constructions mentioned above, both German and English children have to learn (i) when to use pronominal or a non-pronominal constructions and (ii) when to use a construction with a non-prepositional PR rather than a construction with a PR-PP. Moreover, German children have to acquire adnominal constructions with genitive PRs or a combination of dative PRs and possessive pronouns - though we won't be able to investigate this aspect of the acquisition process due to a lack of relevant data.

With respect to the choice of pronominal vs. non-pronominal constructions, German and English are similar: possessive pronouns are preferred when the PRs can be identified on the basis of contextual or discourse information. As this is particularly easy for speakers and hearers, adults tend to use $1^{\text {st }}$ and $2^{\text {nd }}$ person possessive pronouns rather than names when they talk to other adults (e.g. mein-e/dein-e Henne 'my/your chicken'). However, in children's early language and in language directed at young children, we can often observe the use of names and kinship terms instead of $1^{\text {st }}$ and $2^{\text {nd }}$ person possessive or personal pronouns (e.g. Ruff 2000). For instance, a mother might tell her daughter Jane: Das ist Jane-s Auto; und das ist 
Mama-s Auto 'this is Jane's car; and this is mommy's car'. Thus, we will have to investigate when and for which types of PRs children use possessive pronouns.

Whether a prepositional or a non-prepositional construction is chosen, depends on a range of factors. The first factor is the syntactic status of the PM: if it is an unmodified noun such as the proper name Paul, it can either appear with a prepositional PR as in (3d) or with a non-prepositional PR as in (3c). However, possessive pronouns as well as $-s$-marked PRs induce a definite reading and cannot co-occur with determiners or wh-elements (*ein/dieser/welcher Pauls/mein Freund 'a/this/which Paul's/my friend). Thus, the use of a wh-question or an intended indefinite reading may require a prepositional construction. We will now look at factors that play a role if the choice of construction is not already determined by the type of PR.

For pronominal PRs, English or German speakers have a choice between a possessive pronoun construction as in (3a) and a prepositional construction with a pronoun as in ( $3 \mathrm{~b})$; the possessive pronoun construction is typically preferred as PR phrases tend to proceed the PR, especially when they are short, animate and topical and the PR is not used contrastively, see e.g. $m y$ friend vs. ?the friend of mine.

For non-pronominal PRs, English and German differ with respect to the factors that determine their choice of construction. In English, $-s$ can attach to non-pronominal PR phrases of any syntactic complexity (e.g. Jack's/the old farmer's chicken farm). Similarly, prepositional constructions can involve simple PR nouns or complex PR noun phrases (e.g. a teacher of Jane/ my little daughter). Thus, for non-pronominal PR phrases, English speakers have a choice between $-s$ and $o f$. This choice is determined by the animacy, topicality and syntactic weight of the PR and by the type of possessive relationship: $-s$ is preferred for prototypical and inalienable possessive relations and when the PR is animate, topical and short (e.g. Sue's eyes) - whereas of is preferred when the PR is inanimate, not topical and syntactically modified and the relationship between PR and possesum is not a close and prototypical possessive relation (e.g. the fumes of a shabby old car; see e.g. Rosenbach 2002, 2005, 2008; Jäger and Rosenbach 2006; Denison, Scott, and Börjars 2008 and references cited there for the discussion of these factors and their interaction). Note, however, that while these factors can conspire to make one construction highly preferable over the other, none of these factors on its own can determine the choice of construction.

By contrast, German exhibits a constraint for the use of possessive $-s$ that cannot be violated and hence can uniquely determine the choice of non-pronominal possessive construction: $-s$ can only be combined with PR 
nominals that lack an article or any other modifiers. Typically, these nouns are proper names like Susi, but some kinship terms can also be used without a determiner and can thus be combined with -s (e.g. Mamas/Papas Auto 'mommy's/daddy's car'). This has led some linguists to distinguish possessive $-s$ markers from genitive markers by calling them "proper name possessive markers" (see e.g. Harbert 2007: 161ff.). We will argue that the constraint on the use of $-s$ is a syntactic constraint and not a restriction of $-s$ to a particular semantic class of nouns. In many regional variants of colloquial German, kinship terms or proper names appear with determiners (e.g. die/ eine Mama 'the/a daddy' or die Emma 'the Emma'). However, when such phrases are used as PRs, $-s$ cannot be used (e.g. *der Mamas/Emmas Auto 'the mommy's/Emma's car'). Rather, a prepositional construction is chosen (e.g. das Auto von der Mama/Emma 'the car of the mommy/Emma). Thus, it is not the type of noun per se that determines whether $-s$ can appear, but the lack vs. presence of determiners or other modifiers.

Given the syntactic constraints for $-s$, German speakers can only choose between $-s$ and the prepositional von-construction when the PR is an unmodified proper name such as Emma or name-like kinship term such as Mama 'mommy'. As the referents of these nouns are all animate and the length of the PR phrase is limited to one word, animacy or syntactic weight cannot determine the choice between an $-s$ construction like Annas Auto 'Anna's car' and a prepositional construction like das Auto von Anna 'the car of Anna'. However, the type of possessive relationship might play a role, with $-s$ being preferred for closer and more prototypical possessive relationships. To our knowledge, this has not yet been investigated thoroughly.

To summarise, German and English both have possessive constructions with pronominal and non-pronomial PRs; and the choice of pronominal vs. non-pronominal PRs is determined by similar pragmatic factors. Moreover, in both languages, possessive pronouns are preferred to prepositional phrases with pronominal PRs - unless the PR requires a modifier. However, in German and English non-pronominal possession constructions, additional factors play a role: the choice between $-s$ and prepositional constructions for non-pronominal PRs is determined by semantic and discourse factors in English, whereas the use of the German possessive marker is restricted to particular syntactic environments - i.e. unmodified nominals. Thus, a choice between $-s$ and the prepositional construction is only available for proper names and a few kinship terms that can appear without a determiner.

Not all languages show such a competition between a prepositional construction and a construction with a possessive marker. For instance, in Japa- 
nese, all PR phrases, whether they are personal pronouns, unmodified nouns or more complex noun phrases, are marked by the postposition no and precede the PM (e.g. watashi/Toshiko no kuruma 'I/Toshiko's car). In Hebrew, the PR is marked by the preposition shel and follows the possesum (e.g. pe shel buba '(the) mouth of (the) doll'). The PR $<$ PR order can also be observed in constructions with possessive pronouns (e.g. hasefer sheli 'the book (of) my/mine'; see e.g. Armon-Lotem, Crain, and Varlokosta 2005).

Even in a language with only one possessive marker for non-pronominal constructions, children may have to acquire different word order patterns: For instance, in Standard Modern Greek, the genitive-marked PR is compatible with determiners for the PR and can either precede the PM as in (4a) or it can follow it as in (4b); see Marinis (2002, 2003):
a. Pira tu nikous to vivlio.
took the-GEN Nikos-GEN the-ACC book-ACC 'I took Niko's book.'
b. Pira to vivlio tu Niku.
took the-ACC book-ACC the-GEN Nikos-GEN
'I took Niko's book.'

Thus, when children acquire the adnominal possession construction of their target language, they have to learn the different markers and the syntactic, semantic, and discourse constraints on their use. They also have to determine the word order options of their target language.

\subsection{Adnominal possession in child language}

In the following, we will first focus on the developmental problem and investigate when children start to produce the adnominal possessive constructions of their target language and whether their earliest uses of these constructions are restricted to particular lexical items - as predicted by structure-building and usage-base approaches. Then, we will study whether children show early sensitivity to the language-specific constraints that govern the choice of construction. Against this background, we will then try to provide an account for the order in which adnominal possessive constructions are acquired and used to encode different types of possessive relations. 


\subsubsection{The course of development}

Table 1 gives an overview of adnominal possession constructions in our German child language data.

Table 1. Adnominal possesssive constructions

\begin{tabular}{|c|c|c|c|c|c|c|c|}
\hline \multirow[b]{2}{*}{ Stage } & \multirow[b]{2}{*}{ Child } & \multicolumn{2}{|c|}{ Pronominal PR } & \multicolumn{3}{|c|}{ Non-Pronominal PR } & \multirow[b]{2}{*}{ Total } \\
\hline & & $\begin{array}{l}\text { possessive } \\
\text { pronoun }\end{array}$ & $\begin{array}{l}\text { von }+ \\
\text { pronoun }\end{array}$ & $\begin{array}{l}\mathrm{PR}+\mathrm{PR} \\
\mathrm{w} / \mathrm{o}-s\end{array}$ & $\begin{array}{l}\mathrm{PR}+\mathrm{PR} \\
\mathrm{W} .-s\end{array}$ & $v o n+\mathrm{NP}$ & \\
\hline \multirow{5}{*}{ I } & Ann & 6 & - & 1 & - & - & 7 \\
\hline & Han & - & - & - & - & - & 0 \\
\hline & Leo & 0 & - & 17 & - & - & 17 \\
\hline & Mat & 3 & - & 3 & - & - & 6 \\
\hline & Total & $9(30 \%)$ & $0(0 \%)$ & $21(70 \%)$ & $0(0 \%)$ & $0(0 \%)$ & 30 \\
\hline \multirow{5}{*}{ II } & Ann & 3 & - & 1 & - & - & 4 \\
\hline & Han & - & - & - & - & - & \\
\hline & Leo & 1 & - & 6 & 1 & - & 8 \\
\hline & Mat & - & - & - & - & - & - \\
\hline & Total & $4(33 \%)$ & $0(0 \%)$ & $7(58 \%)$ & $1(8 \%)$ & $0(0 \%)$ & 12 \\
\hline \multirow{6}{*}{ III } & And & 63 & - & 2 & 2 & - & 67 \\
\hline & Ann & 15 & - & 3 & - & - & 18 \\
\hline & Han & - & - & - & 1 & - & 1 \\
\hline & Leo & 17 & - & 2 & 20 & - & 39 \\
\hline & Mat & 7 & - & - & - & - & 7 \\
\hline & Total & $102(77 \%)$ & $0(0 \%)$ & $7(5 \%)$ & $23(17 \%)$ & $0(0 \%)$ & 132 \\
\hline \multirow{7}{*}{ IV } & Ann & 25 & - & - & - & - & 25 \\
\hline & Car & 105 & 1 & - & - & 4 & 110 \\
\hline & Han & 4 & - & - & 1 & 1 & 6 \\
\hline & Leo & 26 & - & - & 7 & - & 33 \\
\hline & Mat & 31 & - & - & 5 & 1 & 37 \\
\hline & Sve & 75 & 1 & - & 17 & 5 & 98 \\
\hline & Total & $266(86 \%)$ & $2(<1 \%)$ & $0(0 \%)$ & $30(10)$ & $11(4 \%)$ & 309 \\
\hline \multicolumn{2}{|c|}{ Total } & $381(79 \%)$ & $2(<1 \%)$ & $35(7 \%)$ & $54(11 \%)$ & $11(2 \%)$ & 483 \\
\hline
\end{tabular}

This tabulation suggests that there might be an early stage without adnominal possessive constructions: Hannah does not produce any of these constructions in stages I and II and only one proper name possessive construction in stage II. In stage I, she mostly labels or points out objects and actions or asks for things, but does not talk about possessions. From stage II on, possessive relations become a talking point for her and the possessive 
pronoun $\operatorname{mein}(s)$ 'my/mine' appears, but only in one-word utterances, not in combination with a PM noun. This seems to be a precursor for adnominal possessive constructions that emerge in stage III (see Ruff 2000 for similar observations).

When adnominal possessive constructions emerge, they seem to do so incrementally: prepositional constructions can only be found in data from stage IV - and even then only Carsten and Svenja produce more than one of these constructions, see e.g. $(5 \mathrm{a}, \mathrm{b})$. This suggests that prepositional constructions are a late acquisition, though they seem to be acquired earlier than the more formal genitive construction, which does not occur in our data at all. Similar observations have been made by Ruff (2000) in her longitudinal study with 7 German children (age range at beginning of recordings: $2 ; 0-2 ; 9$; age at the end: $2 ; 4-3 ; 2)$.
a. mama und wo is der kopp hier
mommy and where is the head here
von den junge von diesen?
ofthe boy of this-one?
'Mommy, and where is the head of this boy?'
b. ich bin der hund von Sewenja (= Svenja).
I am the dog of Svenja.
'I am Svenja's dog.'
$(\text { Carsten } / 3 ; 6)^{4}$

Both proper noun possessive constructions as in (6a) and possessive pronoun constructions as in (6b) can already be found in stage I, though proper noun possessives seem to emerge earlier. In stage I, Leonie only produces 17 proper noun possessives, but no possessive pronoun, and in stage II she uses 7 proper noun PRs, but only one possessive pronoun. And when Hannah starts to use adnominal possessive constructions, her first construction contains a proper noun PR. Moreover, we can observe a shift towards pronominal PRs: In stages I and II, only 31\% (13/42) of all adnominal possessive constructions involve a pronominal PR, compared to $84 \%(370 / 441)$ in stages III and IV. In stage IV, each of the children uses predominantly pronominal PRs. Carsten does not use proper name possessive constructions at all, but this is probably due to the fact that he uses the dative possessive construction, which is a regional variant, instead (see (6c)). However, even this construction only occurs three times.

${ }^{4}$ Recording information is provided in the following format: (Name/number of recording/age). 
(6) a. S.E.: das is mamas koffer. ne?

(Leonie/01/01;11)

this is mommy's suitcase. TAG?

und das da?

and that there?

'This is mommy's suitcase, isn't it? And that one over there (is)?'

Leonie: mann koffer.

man('s) suitcase

'(the) man('s) suitcase'

b. mein puppe $i$ weg.

my doll is gone.

(Annelie/02/2;5)

'My doll is gone.'

c. das is oma ihr lesezeichen mama

that is granny her bookmark, mommy

(Carsten $/ 3 ; 6)$

'That is granny's bookmark, mommy.'

The observed shift towards pronominal PRs cannot simply be due to children initially preferring their own name for self-reference: of the seven children, only Annelie, Hannah, and Leonie ever employ their own name as PRs; and Annelie and Leonie use both the possessive pronoun and their own name as soon as they talk about themselves as PRs. Hannah produces her name only once in an adnominal possessive construction (stage II) before she starts using both the possessive pronoun and her own name (stage III). But recall that she already used the possessive pronoun in one-word utterances in stage II. Thus, those children who use their own name for selfreference in adnominal possessive constructions do not seem to do so because they have not yet acquired pronouns. Rather, they exhibit an alternation between pronouns and their names in these constructions.

As we do not have video data available to study the details of the situational context, we cannot investigate all factors that determine when a possessive pronoun is chosen. However, an alternation between pronominal and non-pronominal references to the speaker as PR has also been observed by Ruff (2000) who argues that possessive pronouns are initially used in demands and conflict situations, whereas non-pronominal PRs appear in descriptive utterances. Moreover, Ruff reports that German children use pronouns more frequently when the speaker is the PR than when the addressee is the PR.

Taken together, we observe an incremental development of possessive constructions, with a late acquisition of prepositional constructions and a 
shift towards pronominal constructions. While capturing these observations would require additional assumptions in full-competence approaches, it is explicitly predicted by both usage-based approaches and generative structure-building approaches. These approaches are also compatible with an early stage during which possessive markers are omitted; and they predict initial restrictions to particular lexical elements once they do occur. For possessive $-s$ markers, Eisenbeiß $(2000,2003)$ has already demonstrated that the German children we are investigating go through an early stage without $-s$ (see also Table 1). Note that in stages I and II, $-s$ is even omitted when the target form occurred in the preceding discourse, see e.g.:

$$
\begin{aligned}
& \text { S.E.: Und Papas Hose brauchen wir noch } \\
& \text { and daddy's trousers need we still } \\
& \text { 'and we still need daddy's trousers' (Leonie/03/2;1) } \\
& \text { Leonie: } d a \text { papa hose } \\
& \text { there daddy('s) trousers. } \\
& \text { 'there (are) daddy('s) trousers.' }
\end{aligned}
$$

An early stage with omissions of possessive markers has also been observed for other German children and in studies of the corresponding possessive markers in English, Greek, Hebrew and Japanese (Clahsen, Eisenbeiß and Vainikka 1994; Penner and Weissenborn 1996; Brown 1973; Radford 1990; Radford and Galasso 1998; Marinis 2002, 2003; Berman 1985; Armon-Lotem 1998; Clancy 1985). Proponents of full-competence approaches have tried to show that possessive markers appear early even if they are not always realised. For instance, Bohnacker (1997) argued that possessive markers appeared in the data of a young Swedish child (Embla; age: $1 ; 8-2 ; 1)$. However, the entire corpus only contained 14 possessive markers; and none of these occur at the beginning of the recording period (Eisenbeiß 2003). Still, it is not clear whether all children in all languages go through a stage in which possessive markers are omitted. Note, however, that structure-building and usage-based approaches do not in principle rule out the possibility that possessive markers appear early - they simply allow for the gradual and incremental acquisition of such markers and the possibility of an early, marker-less stage. In fact, for languages where the possessive marker is frequent, obligatory, salient (e.g. syllabic) and not homonymous with any other marker, proponents of structure-building and usagebased approaches would expect this marker to be acquired quite early. 


\subsubsection{Lexical restrictions of possessive markers and pronouns}

With respect to the early use of possessive markers, studies of German, English, Japanese, and Hebrew have demonstrated that adnominal possessive constructions with target-like markers can temporarily co-occur with constructions that lack such markers (e.g. Brown 1973; Berman 1985; Clancy 1985; Peters/Menn 1993; Clahsen, Eisenbeiß and Vainikka 1994, 2000; Penner and Weissenborn 1996; Armon-Lotem 1998; Radford and Galasso 1998; Ruff 2000). For instance, Clahsen et al. (1994) showed that the German child Simone provided the $-s$ only in 33 of the 49 proper noun possessives she produced between 2;0,25 and 2;2,21.; and the English child Nicholas used 's only in 14 of 60 obligatory contexts between $3 ; 2$ and 3;6 (Radford and Galasso 1998). A similar stage can be observed in the data of Leonie and Andreas who produced $-s$ only in 8 out of 29 and 2 out of 4 obligatory contexts in stage IV (see Table 1 and Eisenbeiß 2000).

Independently of the language under investigation, the early examples of possessive markers that are reported in the literature typically involve kinship terms like dad or the name of the child or close friends and relatives (e.g. Clancy 1985: 458; Mills 1985: 185; Radford 1990: 89; Peters and Menn 1993: $757 \mathrm{ff}$; Clahsen, Eisenbeiß and Vainikka 1994: $97 \mathrm{ff}$; Stenzel 1994: 196f.; Radford and Galasso 1998: 37). This is compatible with the assumption that the use of possessive markers is initially lexically restricted to individual nouns that children hear frequently with this marker. Further evidence for this hypothesis comes from the observation that the Englishspeaking child Daniel combined $-s$ with the name Mike, then with the kinshp term mommy and only later with other PRs (Peters and Menn 1993). Similarly, Leonie goes through a stage where she uses $-s$ with familiar names and kinship terms as in (8a), but not with the name Sonja, which she had not been familiar with before the start of recordings as in (8b). Even though she heard the form Sonjas during the recordings, she does not use this marker herself until the last recording in stage II. Similarly, in the recording we investigated Andreas consistently uses $-s$ with papa 'daddy' as in (8c), but always omits it with mama 'mommy' as in (8d).

(8) a. is mamis

(Leonie/05/2;3)

is mommy's

'(This) is mommy's.'

b. S.E.: Und welches ist Sonjas Auto? (Leonie/06/2;3) and which-one is Sonja's car? 'and which one is Sonja's car?' 
Leonie: Sonja autos

Sonja cars

'Sonja('s) cars' (correct: 'car')

c. hm papas gürtel

(Andreas $/ 2 ; 1)$

hm papa's belt

'papa's belt'

d. e mama ticktack is(t) das

(Andreas/2;1)

e mommy ticktack is that

'That is mommy's clock.'

One could attribute the early omissions of possessive markers and the initial lexical restrictions to non-syntactic factors, e.g. to the fact that possessive markers are typically unstressed and that some combinations of PRs and possessive markers might be more difficult to hear or pronounce. However, Eisenbeiß $(2000,2003)$ has argued that phonological factors alone cannot account for the distribution of possessive markers in the corpora we analysed. For instance, the word Papa 'daddy', which Andreas uses with $-s$, and the word Mama 'mommy', which appears without $-s$, have the same syllable structure and the same final vowel.

Moreover, a distributional analysis of the possessive pronouns in our corpora offers further support for the assumption of initial lexical restrictions. In stages I and II, only Annelie and Mathias produce more than one possessive pronoun in an adnominal possessive construction; and the 9 instances of possessive pronouns in Annelie's early data only involve 5 highfrequency nouns (puppe 'doll', mama 'mommy', schuhe 'shoes', zimmer 'room', and bilder 'pictures'). Similarly, in stages I and II, Mathias only produces 3 types of adnominal possessive constructions with the possessive pronouns. Finally, all possessive pronouns in stages I and II are forms of mein 'my'; forms of dein 'your', unser 'our' or sein 'his' as in (9) do not occur until stages III and IV.

(9) $d a$ da is doch seine mama.

$($ Svenja/08/3;0)

there there is PART his mommy

'there is his mommy'

At the same time, agreement with the PR is not target-like: except for one use of the correct plural form meine in stage II (meine bilder 'my pictures'), Annelie only uses the uninflected form mein, which leads to agreement errors for feminine and plural nouns that require the form meine (e.g. * mein mama 'my mommy'). Mathias produces the uninflected form mein once, in 
an appropriate context. The remaining two possessive pronouns are incorrectly inflected (*meiner buch 'my book', *meiner lappen 'my rag'). Thus, both the range of possessive pronouns and their combinations are limited initially. This is in line with studies that observed that English-speaking and German children initially only used possessive pronouns when the PR was the speaker (Tomasello 1998; Ruff 2000).

\subsubsection{Sensitivity to language-specific constraints}

While the previous section showed quite a few studies of the time course of the acquisition process in the domain of adnominal possessive constructions, there are fewer studies of the constraints that govern the use and choice of these constructions, which is somewhat surprising given the rich theoretical literature on the topic. We have already discussed the choice between pronominal and non-pronominal constructions above (see Ruff 2000 for more details).

With respect to non-pronominal possessives, we observed earlier that the possessive marker $-s$ is restricted to unmodified PR nouns in German typically proper names like Susi, and some kinship terms (e.g. Mamas/Papas Auto 'mommy's/daddy's car'). Thus, for modified PR nouns (e.g. das kleine Huhn 'the (little) chicken'), German speakers have to use a prepositional or genitive construction (e.g. der Kopf von dem kleinen Huhn or der Kopf des GEN $_{\text {kleinen }}$ GEN Huhns $_{\mathrm{GEN}}$ 'the head of the little chicken'). This raises questions with respect to German child language: as we observed earlier, prepositional and genitive constructions do not appear in our data in stages I-III and we only found a few prepositional constructions in some files from late stage IV. At the same time, noun-modifying determiners emerge in stage III and appear in nearly all obligatory contexts in stage IV. Thus, what do young German children do when the PR is a common noun that requires a determiner or some other modifier - and is thus incompatible with $-s$ ? In principle, they could refrain from using any non-pronominal adnominal possessive constructions with PRs that require a modifier until they have acquired the prepositional or genitive constructions of their target language, but - as we will see - that does not seem to be what happens. Thus, children could do one of three things. The first option is to use an $-s$ possessive but to omit the required noun modifier. This would not violate the German constraint for $-s$, though it would mean treating a common noun like a proper noun. As reported ir enbeiß (2000), two of the children we investigated exhibited the seoption: Svenja produced one and Leonie 
produced two overgeneralizations to an unmodified PR in an adnominal possessive construction, as in $(10 \mathrm{a}-\mathrm{c})$.

(10) a. S.E.: Das is?

(Leonie/07/2;4)

that is?

'That is (what)?'

Leonie: affes banane

monkey's banana

'the monkey's banana'

b. clowns hut

(Leonie/11/2;7)

clown's hat

'the clown's hat'

c. das is junges gürtel

this is boy's belt

'this is the boy's belt'

(Svenja/13/3;2)

While this is clearly a very small set of examples, more can be found in the literature: see (11) for $-s$ overgeneralizations reported by Mills (1985: 185). What is striking about this set of examples is that it contains a plural noun, which can definitely not be interpreted as a proper name. Thus, children do not seem to violate the constraint on the affixation of $-s$ to modified nouns. They DO violate the requirement to use determiners with count nouns. Note, however, that some German speakers who we showed the examples to commented that adnominal possessive constructions such as affes $b a$ nane are acceptable if one analyses the respective PR noun as a proper name, which would not require a determiner in German.

(11) a. das is männers wagen

(Scupin $3 ; 1)$

that is men's car

'That is the men's car'

b. hier is männers wohnung

(Scupin 4;3)

here is men's apartment

'Here is the men's apartment'

c. da tut männers bauch weh

(Scupin 4;4)

there does men's tummy ache

'The men's tummies are aching here.'

d. an elefantes zähne

(Scupin 5;8)

on elephant's teeth

'on the elephant's teeth' 
The second option for children faced with the dilemma of either violating the $-s$ or the determiner constraint would be to use a modified PR and omit $-s$, thus producing a construction that exhibits a modifier, but does not show the required $\mathrm{n} \equiv$ hological marking. We do not have a lot of evidence for the first option, only one example, which we did not include in our counts as the interruption in it makes it difficult to interpret:

(12) darf ich mein mama [/] mein mama bademütze haben? may I my mommy [/] my mommy swimming.cap have?

'May I have my mommy's swimming cap?' (Annelie/04/2;7)

What is striking, however, is that we did not find any evidence for the third option: overgeneralisation of $-s$ to a modified PR noun, i.e. a violation of the constraint on $-s$ that would avoid treating the PR noun like a proper noun. That is, we did not observe any "English-style" constructions such as mein Mamas bademütze 'my mommy's bathing cap'. This is quite surprising as children DO obviously overgeneralise $-s$. Moreover, most of the nouns that the children in our sample correctly use as $-s$-PRs could be modified in the target language because kinship terms and even proper nouns may be combined with determiners or some other modifiers in most varieties of spoken German - even though they do not HAVE TO. And indeed all children in our sample that produce $-s$-PRs provide modifiers for the nouns they use as $-s$ PRs when they appear in other contexts: Andreas affixes $-s$ to papa 'daddy' when it is an unmodified PR (as in (8c) above), but he combines this noun with a possessive pronoun in other contexts (as in (13a)). Hannah only uses her own name in an $-s$ possessive construction, but at the same time she mostly combines her name with determiners in other contexts, see e.g. (13b). Mathias only uses unmodified proper nouns with $-s$, but he produces combinations of these nouns with determiners in other contexts (e.g. (13c)). Leonie produces $-s$ overgeneralisations from stage III on, but the PR nouns she uses with $-s$ appear without a determiner, though they are used with modifiers in other contexts, as in (13d). The PR nouns that appear with an overgeneralized $-s$ marker in stage III and IV, occur with determiners during the same stage, as in (13e). Svenja also combines $-s$ with nouns that she otherwise uses with articles and other modifiers, see e.g. (13f), including the common noun junge 'boy', which she incorrectly affixes with $-s$. Moreover, Svenja is one of those children that already show a contrast between the $-s$ construction and the possessive construction; and we find minimal pairs with an unmodified proper name or kinship term in the $-s$ construction and the same name with a modifier in the prepositional construction of $(13 \mathrm{~g}, \mathrm{~h})$. 
(13) a. mein Papa macht wieder drauf.

(Andreas $/ 2 ; 1)$

my daddy makes again onto-this.

'My daddy puts (it) on that again.'

b. da is die Hannah.

(Hannah/06/2;6)

there is the Hannah.

'There is Hannah.'

c. der Daniel hat das puttmach.

(Mathias/21/3;0) the Daniel has that broken.

'Daniel has broken that.'

d. un(d) de (/) die große Sonja. and the (/) the tall Sonja 'And the tall Sonja.'

e. da ist wieder der clown mit den kalten füßen, ne? there is again the clown with the cold feet, TAG? 'There is the clown with the cold feet again, isn't he?'

f. nein das is doch kein papa!

(Leonie/09/2;6)

no that is PART no daddy!

(Svenja/05/2,10)

'No, that isn't a daddy!'

g. Saschas hut

$($ Svenja/13/3;2)

Sascha's hat

'Sascha's hat'

h. von die

(corr: dem)

Sascha.

of the-NOM/ACC.FEM.SG (corr:DAT.MASC.SG.) Sascha

'Sascha's'

(Svenja/13/3;2)

Taken together, these findings suggest that children may overgeneralise $-s$ to common nouns, but they do not violate the constraint that prohibits the combination of $-s$ with modified nouns. They do not even use a modifier for proper nouns and kinship terms in possessive $-s$ constructions when they use these nouns with modifiers in other contexts. This supports the assumption that children are sensitive to a syntactic constraint on the use of $-s$ as soon as we find this marker in their data, while they do not show a general restriction of $-s$ to proper nouns and kinship terms. This is in line with our claim that the constraint on $-s$ is a syntactic and not a semantic constraint in the target language.

Children's early sensitivity to the syntactic constraint on $-s$ raises the question why they do not make the incorrect assumption that the constraint on the use of $-s$ is semantic. That is, we have to explain why they do not 
restrict the use of $-s$ to proper names and kinship terms and overgeneralise $-s$ to modified proper names and kinship terms. We argue that children who hear $-s$ with single nouns would only assume that $-s$ can also be combined with more complex noun phrases if they found positive evidence for this in the input. Thus, children acquiring English would learn to use $-s$ with complex noun phrases because they hear such combinations, whereas German children would never have any evidence that would lead them to extend the use of $-s$ in this way. This means that German children do not have the means to produce any adnominal possessive constructions with modified PR nouns before they have acquired prepositional or genitive constructions. This would leave them only one option: to treat the common PR nouns they want to use as if they were proper names. Note that treating a common noun like a proper name is not that uncommon for nouns with animate referents. For instance, we know quite a few adults who use words such as $b a b y$ and cat as proper names. Thus, children's overgeneralisations are not completely outside the limits of the target language, children are simply stretching these limits when they are faced with a dilemma: violating the syntactic constraint on $-s$ or violating the requirement to use a determiner or other modifier with a count noun. Once prepositional or genitive constructions are acquired, there is no pressure to affix $-s$ to common nouns that require a modifier.

The idea that children need positive evidence to assume that $-s$ can be used for modified PRs can be captured straightforwardly: one could simply assume that children's unmarked expectation would be that bound morphemes will concern the word to which they are attached, rather than the phrase. One could also capture this idea in feature-based underspecification models of morpho-syntactic development - such as the one assumed by Eisenbeiß (2003; see Eisenbeiß 2009 for a summary). In such models, grammatical features are only integrated into morphological representations if there is positive evidence in the input that requires them. For instance, children only integrate number features into lexical entries for nouns when they are confronted with contrasts between singular and plural forms. The difference between a simple noun and a complex noun phrase is captured by additional features for phrasal projections in different syntactic frameworks (see e.g. Grimshaw 1994). Thus, one could assume that English children include such a phrase-feature in their input specification for 's because they find positive evidence in their input that supports this. In contrast, German children do not find such positive evidence and thus do not extend the range of elements that can be affixed by $-s$. 
Interestingly, there is some initial evidence for such a conservative approach in Carsten's data. The three adnominal possessive constructions with a dative PR that Carsten produces all involve an unmodified noun, even though the noun Kind 'child' requires a determiner in adult German and Carsten uses it with modifiers in other contexts, as in (14a), and produces determiners in almost all obligatory contexts. This is compatible with the assumption that he initially restricts the use of this construction to unmodified nouns. Similarly, Penner and Weissenborn (1996) provide a few examples for the emergence of dative possessive constructions in Swiss German and the earliest examples with an overt possessive pronoun also involve unmodified PR nouns, as in (14b). However, the data base is currently too limited to warrant a stronger conclusion. Moreover, children hear adult-like constructions with modified dative PRs when they learn a variety of German that allows them. Thus, they might acquire the appropriate generalisation early on.

(14) a. wi(ll) das kind viele autos? wants the child many cars?

(Carsten/3;6) 'Does the child want many cars?'

b. Nadaw sis Ue $(=u h r)$

Nadaw his watch

'Nadaw's watch'

We already observed that the syntactic factors that determine the choice of possessive construction in German are not relevant for English, where factors such as animacy play a crucial role. So far, no published study seems to have systematically varied all the factors discussed in the literature on adult English, but Armon-Lotem et al. (2005) carried out an elicited production study with English-speaking children $(3 ; 2-6 ; 3)$. These children used 's with count nouns but not with mass nouns; and they used 's with animate PRs $90 \%$ of the time to encode a part-whole relation (the cowboy's arm), but less than $50 \%$ of the time for inanimate PRs (the tractor's wheel).

With respect to the acquisition of the target word order, some studies explicitly mention that possessive pronouns are correctly positioned (see e.g. Ruff 2000 for German) and we are not aware of any reports that children who acquire the languages under study ever incorrectly position the possessive pronoun after the PR noun. Similarly, studies of German -s possessives, English 's-possessives, and Japanese no-possessives report that children show the PR-initial target word order from the beginning (Brown 
1973; Clahsen, Eisenbeiß and Vainikka 1994; Clancy 1985; Eisenbeiß 2000; Radford 1990; Radford and Galasso 1998; Ruff 2000). Both observations also hold for our German data. As we mentioned above, the PR typically follows the PM in German prepositional possessive constructions; and prepositional constructions where the PR precedes the PM are highly marked. However, of the 13 prepositional possessive constructions that we have found in our German data, 3 exhibit the marked PR-initial order $(15 \mathrm{a}-\mathrm{c})$ and one has a fronted prepositional phrase with a wh-element (15d):

(15) a. aber das is nich von wurst die pelle.

(Carsten/3;6) but that is not of sausage the skin. 'But that is not the skin of the saussage'

b. ob deiner auch von diese malers das anspitzt. whether yours also of these crayons that sharpen '(Let's see) whether yours also sharpens that (tip) of these crayons?'

$($ Carsten $/ 3 ; 6)$

c. das is vo von de von de Sascha fahrrad. (Svenja/13/3;2) that is of of the of the Sascha bike.

'That is Sascha's bike.'

d. von wem hast $d u$ die schuhe da an? of whom have you the shoes there on?

(Svenja/08/3;0) 'Whose shoes have you got on, there?'

Note that the examples where the prepositional PR phrase precedes the PM come from different children and corpora and similar examples can easily be found even in a cursory search of the German child corpora in the CHILDES database (MacWhinney 2000); see e.g. the following examples from the corpus provided by Wagner (1985):

(16) aber das sind von Pfe[\#] von der Reitschule Pferde. but that are of hor[\#] of the riding:school horses. 'But that are the horses of the riding school.'

$(\operatorname{Roman} / 9 ; 2)$

For Greek, which exhibits two different orders for PM and PR for non-pronominal adnominal possessive constructions, we cannot draw any firm conclusions about the early stages, due to a scarcity of early data (see Eisenbeiß 2003 for a discussion of Marinis 2002, 2003). For Hebrew, where the PP follows the PM in constructions with the marker shel, Berman (1987) and Armon-Lotem (1998) argue that children produce possessive constructions 
with the non-target-like order PR $<$ PM before they start to use the correct order and then finally the posssssive marker shel.

Taken together, these observations tentatively suggest a tendency to place the PM before the PR, independently of the target language and construction. However, further research is required in this domain as the findings for Hebrew are based on a rather small set of examples and thus have to be taken with caution. Moreover, more systematic corpus searches for prepositional constructions in German child language are required.

\subsubsection{Acquisition orders and conceptual complexity}

Our discussion so far suggests that children acquire the adnominal possessive constructions of their target language incrementally, but show early sensitivity to the constraints on the use of these constructions in their target language. Now, we will have a closer look at the order in which children start to encode different types of possessive relationships. Table 2 gives an overview of the the types of PRs in adnominal possessive constructions (including Carsten's three dative possessive constructions, which were not included in Table 1).

As can be seen in Table 2, all PR (pro)nouns in stages I and II refer to the children themselves or to other people. In stage III, we find a nonhuman, but animate PR as in (10a), but inanimate PRs only appear once in Svenja's data and four times in Carsten's data from stage IV as in (17) and (18). Note, however, that in example (18), where the referent of the possessive pronoun is a vehicle, this PR is construed as having "animate" properties.

(17) die wand von'n (corr: 'm) fenster seh ich. the wall of'the-ACC (corr: DAT) window see I.

'I see the wall of the window.'

$($ Svenja/15/3;2)

(18) dann schleudert er doch nich mehr sein räder then flings he PART not anymore his wheels 'Then he doesn't fling his wheels anymore.'

(Carsten/3;6)

The observed incremental extension in the range of PR types is consistent with the assumption that children start out with more prototypical adnominal possessive constructions that involve a human PR and move on to less prototypical ones with inanimate PR. In order to further evaluate this claim, 
Table 2. The animacy of PRs in adnominal possessive constructions

\begin{tabular}{|c|c|c|c|c|c|c|}
\hline Stage & Child & Self & Human & Other Animate & Inanimate & Total \\
\hline \multirow{5}{*}{ I } & Ann & 7 & - & - & - & 7 \\
\hline & Han & - & - & - & - & - \\
\hline & Leo & - & 17 & - & - & 17 \\
\hline & Mat & 3 & 3 & - & - & 6 \\
\hline & Total & $10(33 \%)$ & $20(67 \%)$ & $0(0 \%)$ & $0(0 \%)$ & 30 \\
\hline \multirow{5}{*}{ II } & Ann & 4 & - & - & - & 4 \\
\hline & Han & - & - & - & - & 0 \\
\hline & Leo & 2 & 6 & - & - & 8 \\
\hline & Mat & - & - & - & - & 0 \\
\hline & Total & $6(100 \%)$ & $6(100 \%)$ & $0(0 \%)$ & $0(0 \%)$ & 12 \\
\hline \multirow{6}{*}{ III } & And & 55 & 12 & - & - & 67 \\
\hline & Ann & 11 & 7 & - & - & 18 \\
\hline & Han & 1 & - & - & - & 1 \\
\hline & Leo & 20 & 18 & 1 & - & 39 \\
\hline & Mat & 5 & 2 & - & - & 7 \\
\hline & Total & $92(70 \%)$ & $39(30 \%)$ & $1(<1 \%)$ & $0(0 \%)$ & 132 \\
\hline \multirow{7}{*}{ IV } & Ann & 20 & 5 & - & - & 25 \\
\hline & Car & 77 & 32 & - & 4 & 113 \\
\hline & Han & 5 & 1 & - & - & 6 \\
\hline & Leo & 24 & 9 & - & - & 33 \\
\hline & Mat & 24 & 13 & - & - & 37 \\
\hline & Sve & 47 & 50 & - & 1 & 1 \\
\hline & Total & $197(63 \%)$ & $110(35 \%)$ & $0(0 \%)$ & $5(2 \%)$ & 312 \\
\hline \multicolumn{2}{|l|}{ Total } & $305(63 \%)$ & $175(36 \%)$ & $1(<1 \%)$ & $5(1 \%)$ & 486 \\
\hline
\end{tabular}

we will look at the types of (po $\equiv$ ive) relations involved in adnominal possessive constructions. Table $2 \overline{\overline{6}}$ (II0ws the types of relationships that adnominal possessive constructions encode in our German child data. Note that we have used a wide sense of "ownership" here that covers temporary possessions as well as legal and habitual possession relations. We will try to distinguish between these later.

As can be seen in Table 3, children's adnominal possessive constructions in stages I and II only involve ownership (as in (6a)) or kinship relations as in (19a)). Constructions encoding relationships between a body part and its owner emerge in stage III, as in (19b), and relationships between objects and their parts only appear in the stage IV data of Svenja and Carsten (see e.g. $(15 \mathrm{a}, \mathrm{b})$ above). None of the children ever uses possessive pro 
Table 3. Types of possessive relations in adnominal possessive constructions

\begin{tabular}{|c|c|c|c|c|c|c|}
\hline Stage & Child & Ownership & Kinship & Body Part & Part of Object & Total \\
\hline \multirow{5}{*}{ I } & Ann & 6 & 1 & - & - & 7 \\
\hline & Han & - & - & - & - & - \\
\hline & Leo & 17 & - & - & - & 17 \\
\hline & Mat & 6 & - & - & - & 6 \\
\hline & Total & 29 & 1 & $0(0 \%)$ & $0(0 \%)$ & 30 \\
\hline \multirow{5}{*}{ II } & Ann & 3 & 1 & - & - & 4 \\
\hline & Han & - & 0 & - & - & 0 \\
\hline & Leo & 8 & 0 & - & - & 8 \\
\hline & Mat & - & 0 & - & - & 0 \\
\hline & Total & $11(97 \%)$ & $1(3 \%)$ & $0(0 \%)$ & $0(0 \%)$ & 12 \\
\hline \multirow{6}{*}{ III } & And & 50 & 12 & 5 & - & 67 \\
\hline & Ann & 12 & 1 & 5 & - & 18 \\
\hline & Han & 1 & - & - & - & 1 \\
\hline & Leo & 36 & 1 & 2 & - & 39 \\
\hline & Mat & 7 & - & - & - & 7 \\
\hline & Total & $106(80 \%)$ & $14(11 \%)$ & $12(9 \%)$ & $0(0 \%)$ & 132 \\
\hline \multirow{7}{*}{ IV } & Ann & 18 & 5 & 2 & - & 25 \\
\hline & Car & 91 & 7 & 11 & 4 & 113 \\
\hline & Han & 6 & - & - & - & 6 \\
\hline & Leo & 27 & 3 & 3 & - & 33 \\
\hline & Mat & 34 & - & 3 & - & 37 \\
\hline & Sve & 71 & 10 & 16 & 1 & 1 \\
\hline & Total & $247(79 \%)$ & $25(8 \%)$ & $35(11 \%)$ & $5(2 \%)$ & 312 \\
\hline \multicolumn{2}{|l|}{ Total } & $393(81 \%)$ & $41(8 \%)$ & $47(10 \%)$ & $5(1 \%)$ & 486 \\
\hline
\end{tabular}

nouns, $-s$ possessives or prepositional constructions for non-prototypical possessive relations (the dog's shadow, the size of the block, the state of the car, etc.) Thus, the earliest adnominal possessive constructions only involve prototypical possessive relations.

(19) a. mein mama

(Annelie/02/2;5)

my mommy

'my mommy'

b. mein nase läuft noch mehr

my nose runs even more

(Annelie/04/2;7)

'My nose is running even more.' 
So far, we have not distinguished between legal ownership and temporary possession, which is simply based on current physical control and proximity. This is difficult to do on the basis of spontaneous speech samples because, in everyday situations, the person who has physical control over something or is close to it, is often also the owner. Thus, we did not attempt to distinguish between legal ownership and physical control for all adnominal possessive constructions. Instead, we searched for utterances in which two possessive relations were encoded in the same utterance - one by a possessive predicate and one within an adnominal possessive construction. We found 10 interpretable utterances of this type in the data of Andreas, Carsten, Leonie, Mathias, and Svenja. In these examples, we can observe a clear distinction between the legal or habitual ownership relation, which is encoded noun-phrase internally, and a temporary ownership or physical control relation, which is encoded at the sentential level. For instance, Andreas has a water ball. In (20), he states that another person, namely Anette has temporarily taken over control of the ball.

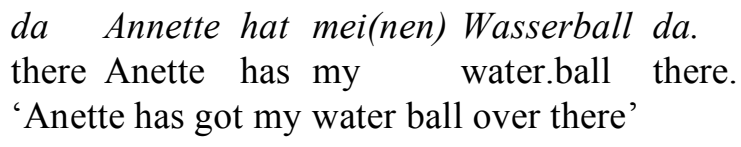

(Andreas $/ 2 ; 1)$

Note that 2 of the 10 utterances that encode two different possessive relations come from Andreas (stage III) and all the others occur in stage IV. One might attribute this to the fact that the combination of two possessive relations in the same utterance requires a certain sentence length. However, some of these sentences are actually only 4 or 5 words long; and in each of stages I and II, we find more than a hundred utterances that are longer than 3 words (see e.g. (6a)). Thus, the appearance of combinations such as (20) in stage III might not be an artifact of increasing sentence length. It is at least in line with the general observation that children in stages III and IV extend the range of PRs and possessive relations from ownership relations with human PRs via body part relations to part-whole relations for inanimate objects.

\subsection{Summary}

Our analysis of the German child data and our literature review lead to the following generalizations: 
- At least some children do not seem to produce adnominal possessive constructions in the early two-word stage, but only precursors, such as single-word utterances that consist of the PR's name or a possessive pronoun.

- German adnominal possessive constructions emerge incrementally, in the order proper name possessives $\leq$ possessive pronouns $<$ prepositional constructions $<$ genitive constructions.

- As children get older, the proportion of pronominal PRs increases.

- An early stage where possessive markers are omitted could be observed in our own data and in studies of the corresponding possessive markers in English, Greek, Hebrew and Japanese.

- Studies of German, English, Japanese, and Hebrew child language have demonstrated that adnominal possessive constructions with target-like markers can temporarily co-occur with constructions that lack such markers.

- In our German data, we observed initial lexical restrictions of possessive pronouns and possessive markers. To our knowledge, detailed analyses of such lexical restrictions have not been carried out for other languages, but the available empirical results we discussed for English possessive ' $s$ are compatible with the assumption of initial lexical restrictions.

- Children show early sensitivity to the constraints on the use of adnominal possessive constructions in their target language: German children overgeneralise the $-s$ marker to common nouns that do not take this marker in the target language. However, children do not violate the syntactic constraint that prohibits the use of $-s$ for modified PRs - not even for those PRs that they themselves use with modifiers in other contexts. An experimental study of English child language also showed early sensitivity to some of the factors that determine the choice of adnominal possessive construction, in particular animacy and the count/mass distinction.

- Children also seem to adapt to the target word order early on, though we found a few fronted prepositional PRs in our own data and there are some reports about non-target-like PR-initial constructions in child Hebrew.

- The German children we observed showed an incremental extension in the range of PRs and possessive relations that were encoded in adnominal possessive constructions - from ownership relations with human PRs via body part relations to part-whole relations for inanimate objects.

Taken together, these empirical generalisations suggest that children show early sensitivity to the constraints of their target language. Thus, the analysis of adnominal possessive constructions provides additional evidence for the 
emerging consensus about early adaptations to the target language. However, our observations tentatively suggest a tendency to place the PM before the PR, independent of the target language and construction - though further research is required to establish whether this is a reliable finding. With respect to the time-course of development, we found evidence for an incremental extension both in the range of constructions and in the range of possessive relations that are encoded by these constructions. This can be captured straightforwardly in lexical learning and usage-based approaches as they explicitly predict that possessive constructions are acquired incrementally. By contrast, full-competence approaches would need to make additional assumptions to account for these observations. In addition, fullcompetence approaches do not directly predict the initial lexical restrictions that we observed for possessive markers or function words such as possessive pronouns. Such initial lexical restrictions are, however, to be expected if one adopts a Lexical learning or usage-based approach as these approaches assume that children's early generalisations are limited and linked to particular lexical elements.

\section{Predicative possession}

In contrast to the acquisition of adnominal possessive constructions, the acquisition of predicative possession constructions has not been studied extensively. We are only aware of a few studies which have investigated the acquisition of possessive constructions with have and belong to evaluate approaches to syntax-semantic mappings. We will discuss these studies briefly below, though they are inconclusive as the data base is quite limited and there is considerable controversy about the availability of constraints on the mapping of PR and PM to argument structure positions (see e.g. Bowerman 1990; Pinker 1984). Therefore, we will focus on empirical generalisations about predicative possessive constructions that were established in cross-linguistic studies and can inform acquisition studies of predicative possessive constructions. In what follows, we first overview these generalizations and their application to German before we discuss our German child language data and relevant findings for English child language.

\subsection{Predicative possession in adult language}

The background for all discussions of predicative possessive constructions is the realization that the possessive relation they encode is a binary and 
"symbiotic" relationship between two entities that only receive their semantic interpretation by virtue of one another: a possessive relation is "a relation between two entities, a PR and a PM, such that one, the PR, is seen as being in some way related to the other, the PM, as having it near or controlling it" (Baron, Herslund, and Sørensen 2001: 2). However, there is no PR without a $\mathrm{PM}$ and a PM is not a PM without a PR. Possessive relations share this property with locative constructions and experiencer constructions: something is only conceived of as a Location if something is located there and this element is only considered to be a Locatum if it has a Location. Similarly, an Experiencer requires a Stimulus to experience something, just as a stimulus cannot be construed as a Stimulus unless it causes a sensation in an Experiencer. By contrast, Agents do not necessarily need Patients for their activities - we can talk about people who kick, dance, and write without ever specifying who they kick or what they dance or write.

Given this inherent co-dependency between the entities involved in a possessive, locative or experience relationship, it is difficult to rank these entities according to their agentivity or their control over the relationship i.e. with respect to the variables that (co-)determine which of them is linguistically realized as the topic or grammatical subject of a construction. Hence, it is unsurprising that we can observe a large amount of inter- and intra-language variability in the syntactic realization of Experiencers and Stimuli, Locata and Locations, and PRs PMs (see e.g. Chappel and McGregor 1996; Heine 1997; Faylor 1996- $\overline{\bar{\sigma}}$ ler 1983). An Experiencer can be realized as topic or subject (Most farmers fear angry roosters) or it can be encoded as an object (Angry roosters frighten most farmers) - and the same is true for the Locatum (The pencils are (lying) in the box vs. The box contains some pencils).

Similarly, cross-linguistic studies of predicative possession constructions frequently make a distinction between HAVE-constructions, where the PR is realized as topic and subject (I have/own a car), and BELONGconstructions, where the PM appears in this role (The car belongs to me. The car is mine/Peter's; see e.g. Baron, Herslund, and Sørensen 2001 for overview). Some authors have claimed that this distinction can be observed in all human languages (Heine 1997: 33), though this is controversial.

HAVE and BELONG constructions do not just differ with respect to the mapping of arguments onto grammatical roles; they can also differ with respect to the definiteness of their arguments. In particular, the PM is typically defninite in German BELONG constructions, but indefinite in German HAVE constructions (Heine 1997: 30 f., see e.g. Das Huhn gehört mir 'The chicken belongs to me' vs. Ich habe ein Huhn). Note, however, that it is 
possible to combine a definite PM with haben 'have', especially when a contrastive reading is intended (Ich habe den linken Schuh, aber nicht den rechten 'I have the left shoe, but not the right one'). By contrast, the restriction against combining gehören 'belong' with an indefinite PM seems quite strict. Whether children are sensitive to the definiteness contrast between HAVE and BELONG constructions has - to our knowledge - not been investigated so far and we try to fill this gap.

Both HAVE- and BELONG-constructions are not restricted to encoding ownership; they can also be used to express locative relations (Boston has many great buildings. This district has always belonged to London, etc.). However, HAVE constructions can express a wider set of meanings (kinship, abstract possession as in She has a cold, etc.), while BELONG constructions tend to encode more concrete relations. Therefore, many linguists consider HAVE constructions the unmarked option (see Baron, Herslund, and Sørensen 2001 for discussion). However, in his discussion of learnability issues in first language acquisition, Pinker (1984) argues that the unmarked or "canonical" mapping is the one where the Locatum Argument becomes the subject. This would make HAVE-constructions the marked alternative. Bowerman (1990) argues that this would lead to the prediction that children should initially make "default marking errors" and produce HAVE-constructions with PM subjects and PR objects. However, such errors have not been observed yet - and in later work, Pinker no longer makes the assumption of canonical mappings (Pinker 1989). In the following, we will investigate whether we find any evidence for non-target-like mappings of PR and Possessum onto grammatical functions - and whether they follow the HAVEor the BELONG-pattern.

Moreover, we will investigate the relationship between the encoding of locative and possessive relations. According to Heine, possession exhibits various structural similarities with domains such as location, experience and existence and predicative possessive constructions draw on different preexisting constructions or "source schemata" (see Baron et al. 2001 for discussion). The most commonly cited ones are the action schema, which underlies HAVE-constructions, and the location schema, which is the basis for BELONG-constructions.

These links raise the question of whether children show any evidence for the primacy of location for verbs that are taken to be derived from the locative source schema - i.e., whether they use verbs such as belong or be first with a locative or existential reading (Das gehört hier hin 'This belongs here') and only later with a possessive reading. 
Note, however, that some linguists argue that possession is independent of location - hence they would not assume that locative constructions form the source of possessive constructions (see e.g. Payne this volume).

\subsection{Predicative possession in child language}

In the following, we will look at HAVE- and BELONG-constructions with the words haben 'have', gehören 'belong' and sein 'be' in our German child language data. Other possession verbs - such as besitzen 'own' - do not occur in our data. We will investigate (i) when the different types of predicative possessive constructions appear in our data, (ii) whether children are sensitive to the fact that HAVE- and BELONG-constructions impose different constraints on the definiteness of the PM, (iii) whether we can find any mapping errors in children's predicative possessive constructions, and (iv) whether children show any evidence for the primacy of location for verbs that are taken to be derived from the locative source schema.

In Table 4, we can see how often children used haben 'have' and gehören 'belong' with a definite PM or an indefinite PM. Moreover, as discussed above, we found 10 instances of haben with a possessive noun phrase (see (20) above) and we listed these utterances in a separate column. As Table 4 demonstrates, predicative constructions with haben 'have' appear before constructions with gehören 'belong'. However, we can see differences between the individual children: Svenja uses both verbs, whereas Hannah, Carsten and Andreas use haben, but not gehören. Annelie used haben from stage I, but gehören 'belong' only appears from stage II. Leonie and Mathias do not exhibit any predicative possessive constructions in stages I and II. In stage III, haben occurs quite frequently and we find one instance of locative gehören in Leonie's data. In stage IV, both children use gehören.

Table 4 also shows that children are sensitive to the definiteness constraint for gehören and do not use any indefinite noun phrases as PM for this verb. Instead, they produce definite articles - either used as pronouns or in combination with nouns as in $(21 \mathrm{a}, \mathrm{b}, \mathrm{c})$ and demonstrative pronouns as in $(21 \mathrm{~d}-\mathrm{g})$. In addition, we found one unclassifiable utterance with a self-interruption that we excluded from the analysis. By contrast, haben predominantly occurred with indefinite noun phrases $(342 / 480=71 \%$, see e.g. (22a), though we also found PM noun phrases with definite articles (22b) and the 10 now phrases with possessive pronouns that we discussed above - see $(20 \mathrm{a} j) . \overline{\bar{\nu}}$ 
Table 4. Types of PM Noun Phrases co-occurring with haben 'have' and gehören 'belong'

\begin{tabular}{|c|c|c|c|c|c|c|c|c|c|c|c|}
\hline & \multirow[t]{2}{*}{ Child } & \multicolumn{4}{|c|}{ haben } & \multicolumn{3}{|c|}{$\begin{array}{l}\text { gehören possessive } \\
\text { ('this belongs to me') }\end{array}$} & \multicolumn{3}{|c|}{$\begin{array}{l}\text { gehören locative } \\
\text { ('this belongs here') }\end{array}$} \\
\hline & & Indef $^{\mathrm{a}}$ & Def & Poss & Total & Indef & Def & Total & Indef & Def & Total \\
\hline \multirow{5}{*}{ I } & Ann & 1 & - & - & 1 & - & - & - & - & - & - \\
\hline & Han & 4 & 1 & - & 5 & - & - & - & - & - & - \\
\hline & Leo & - & - & - & - & - & - & - & - & - & - \\
\hline & Mat & - & - & - & - & - & - & - & - & - & - \\
\hline & Total & $\begin{array}{c}5 \\
(83 \%) \\
\end{array}$ & $\begin{array}{c}1 \\
(17 \%)\end{array}$ & 0 & 6 & 0 & 0 & 0 & 0 & 0 & 0 \\
\hline \multirow{5}{*}{ II } & Ann & 7 & - & - & 7 & - & - & - & - & 4 & 4 \\
\hline & Han & 2 & - & - & 2 & - & - & - & - & - & - \\
\hline & Leo & - & - & - & - & - & - & - & - & - & - \\
\hline & Mat & - & - & - & - & - & - & - & - & - & - \\
\hline & Total & $\begin{array}{c}9 \\
(100 \%) \\
\end{array}$ & 0 & 0 & 9 & 0 & 0 & 0 & 0 & $\begin{array}{c}4 \\
(100 \%)\end{array}$ & 4 \\
\hline \multirow{6}{*}{ III } & And & 54 & 18 & 2 & 74 & - & - & - & - & - & - \\
\hline & Ann & 33 & 2 & - & 35 & - & - & - & - & - & - \\
\hline & Han & - & - & - & - & - & - & - & - & - & - \\
\hline & Leo & 12 & 11 & - & 23 & - & - & - & - & 1 & 1 \\
\hline & Mat & 7 & - & - & 7 & - & - & - & - & - & - \\
\hline & Total & $\begin{array}{l}106 \\
(76 \%)\end{array}$ & $\begin{array}{c}31 \\
(22 \%)\end{array}$ & $\begin{array}{c}2 \\
(1 \%)\end{array}$ & 139 & 0 & 0 & 0 & 0 & $\begin{array}{c}1 \\
(100 \%)\end{array}$ & 1 \\
\hline \multirow{7}{*}{ IV } & Ann & 12 & 11 & - & 23 & - & - & - & - & 1 & 1 \\
\hline & Car & 45 & 9 & 2 & 56 & - & - & - & - & - & - \\
\hline & Han & 9 & 4 & - & 13 & - & - & - & - & - & - \\
\hline & Leo & 47 & 11 & 2 & 60 & - & 1 & 1 & - & 6 & 6 \\
\hline & Mat & 28 & 12 & 2 & 42 & - & 1 & 1 & - & - & - \\
\hline & Sve & 81 & 48 & 2 & 131 & - & 14 & 14 & - & 7 & 7 \\
\hline & Total & \begin{tabular}{|l|}
222 \\
$(68 \%)$
\end{tabular} & $\begin{array}{c}95 \\
(29 \%) \\
\end{array}$ & $\begin{array}{c}8 \\
(6 \%) \\
\end{array}$ & 325 & 0 & $\begin{array}{l}16 \\
(100 \%) \\
\end{array}$ & 16 & 0 & $\begin{array}{l}14 \\
(100 \%) \\
\end{array}$ & 14 \\
\hline \multicolumn{2}{|c|}{ Total } & \begin{tabular}{|l|}
342 \\
$(71 \%)$
\end{tabular} & $\begin{array}{l}127 \\
(26 \%)\end{array}$ & $\begin{array}{l}10 \\
(2 \%)\end{array}$ & 480 & 0 & $\begin{array}{l}16 \\
(100 \%)\end{array}$ & 16 & 0 & $\begin{array}{l}19 \\
(100 \%)\end{array}$ & 19 \\
\hline
\end{tabular}

${ }^{a}$ Def: Definite NP, Indef: Indefinite NP, Poss: adnominal possessive construction

Note that all of the utterances with haben are target-like with respect to definiteness and with respect to the mapping of arguments onto grammatical roles. By contrast, we find mapping problems with gehören. Svenja never uses target-like dative marking for the PR. In examples (21b) and 
(21h), PR noun phrase. In $(21 \mathrm{c}-\mathrm{g})$, she produces nominative forms. Similar nontarget-like mappings have been observed in the example by Simone that we discussed in the introduction. Simone's resistance to corrections for these deviations from the target suggests that such "errors" are not simply slips of the tongue. Rather, at least some children seem to initially overgeneralise the form-meaning mapping of the HAVE-construction to the BELONGconstruction. This is in line with the assumption that HAVE is the default, but it would surprising if the HAVE-pattern were marked (Pinker 1984).

(21) a. der (ge)hört mir.

(Mathias/26/3;5) this-one belongs me-DAT

'This one belongs to me.'

b. der gehört von den (corr: dem) ( )

this-one belongs of this-one-ACC (corr: DAT) (Svenja/13/3;2)

'This one belongs to this one'

c. wer (ge)horn die füße?

who-NOM belong the-NOM/ACC feet?

'To whom do the feet belong?'

d. denn kuck mal hier wer das $d(=g)$ ehört.

then look PART here who-NOM that-NOM/ACC belongs

'Then just look here, to whom that belongs.' (Svenja/13/3;2)

e. der (corr: dem) (ge)hört das ne?

this-one-NOM (corr: DAT) belongs that-NOM/ACC TAG?

'That belongs to this one, doesn't it?' (Svenja/16/3;3)

f. der (corr: dem) (ge)hört das. (Svenja/16/3;3)

this-one-NOM (corr:DAT) belongs that-NOM/ACC

'That belongs to this one.'

g. dann (g)ehört das

(Svenja/04/2;9)

then belongs that-NOM/ACC

niemand $\quad[\#]$ keiner.

nobody-NOM (corr:DAT) [\#] no-one-NOM (corr:DAT).

'Then that belongs to nobody.'

(22) a. jetz ham(=haben) wir eine.

now have we one.

(Andreas/2;1)

'Now, we have one.' 
b. die schere hat Julia.

(Mathias/17/2;9)

the scissors has Julia

'Julia has the scissors.'

For gehören, we observe more than just mapping problems. The data in Table 4 also suggest that locative BELONG is a pre-cursor for possessive BELONG: of the 3 children who use gehören more than once, only Svenja, the most advanced child, uses both type of constructions. Recall, however, that she shows mapping problems. She also uses the proximity preposition bei 'by' in locative BELONG-constructions and not the target preposition $z u$ 'to', which is directional, as shown by $(23 \mathrm{a}, \mathrm{b})$. These utterances are somewhere between a locative and a possessive construction as they seem to focus on placing an object in the proximity of an animate PR. In Annelie's data we only find 5 cases of the locative variant (24); and Leonie uses the locative variant once in stage III and 6 times in stage IV (25a), but only produces one instance of possessive gehören (25b).

(23) a. das schiff gehört bei dir.

(Svenja/05/2;10) the ship belongs at you.

'The ship belongs to you.'

b. die (ge)hört [\#] ei [\#] die (ge)hört bei (?) dir. this-one belongs [\#] ??? [\#] this-one belongs at (?) you.

'She belongs to you.'

(24) so (ge)hört das hin.

(Annelie/03/2;6)

so belongs that hither.

'That belongs here, like that.'

(25) a. das (ge)hört da drauf.

(Leonie/15/2;11) thatbelongs there onto-this.

'That belongs up there.'

b. Sassa (ge)hört das.

Sascha belongs that.

'That belongs to Sascha.'

In order to further explore the relationship between possession and other semantic domains, we have compared different uses of sein 'be': utterances that focus on location (and existence), as in (26); predication, as in (27); combinations of location and possession, as in (28); and utterances with an adnominal possessive as a subject and a further predication, i.e. utterances 
where something is predicated about something that is said to belong to someone, as in (29). We have also looked at sein in utterances that were used to establish possession, as in (30). In these utterances a PR was either used on its own or in a noun phrase with a PM. We have not distinguished between these two types any further as they fulfill a similar function and appeared with very similar frequencies in each stage. Table 5 provides an overview.

(26) da is die mama

(Annelie/02/2;5)

there is the mommy

'There is mommy'

(27) is en löwe. (Hannah/01/2;0)

is a lion.

'(This) is a lion.'

(28) da is Klaras.

there is Klara's.

(Leonie/09/2;6)

'There is Klara's.'

(29) daniels kopf is härter.

(Mathias/26/3;5)

Daniel's head is harder.

'Daniel's head is harder.'

(30) das is doch Julias schiff.

(Mathias/22/3;1) that is PART Julia's ship.

'But that is Julia's ship.'

As Table 5 shows, sein is predominantly used for predictation and location, though we also find one possessive use and a few utterances where the child talks about the location of a possession. In stage III, possessive uses become more frequent - except for Hannah. Thus, we can see a shift towards more sein utterances involving possessive constructions. However, in contrast to gehören 'belong', utterances with sein involve expressions of possession from early on. But only in stage IV do we find more than one utterance where the subject involves an adnominal possessive construction and a further predication is added. This is in line with the observation that combinations of haben 'have' with adnominal possessive constructions only appear in stages III (Andreas) and IV (Carsten, Leonie, Mathias, and Svenja). The only child to combine both haben and sein with adnominal possessive constructions in stage III is Andreas, who is quite advanced for this stage and already on the verge to stage IV (see Eisenbeiß 2000, 2003). 
Table 5. Types of sein 'be'

\begin{tabular}{|c|c|c|c|c|c|c|c|}
\hline & Child & Location & Predication & $\begin{array}{l}\text { Location }+ \\
\text { Possession }\end{array}$ & Possession & $\begin{array}{l}\text { Predication } \\
+ \text { Possession }\end{array}$ & Total \\
\hline \multirow{5}{*}{ I } & Ann & 24 & 7 & 1 & - & - & 32 \\
\hline & Han & - & 1 & - & - & - & 1 \\
\hline & Leo & - & 2 & 1 & - & - & 3 \\
\hline & Mat & 10 & 8 & 2 & - & - & 20 \\
\hline & Total & $34(61 \%)$ & $18(32 \%)$ & $4(7 \%)$ & $0(0 \%)$ & $0(0 \%)$ & 56 \\
\hline \multirow{5}{*}{ II } & Ann & 29 & 15 & 1 & - & - & 45 \\
\hline & Han & 2 & - & - & - & - & 2 \\
\hline & Leo & 1 & 1 & - & 1 & - & 3 \\
\hline & Mat & 12 & 3 & - & - & - & 15 \\
\hline & Total & $44(68 \%)$ & $19(29 \%)$ & $1(2 \%)$ & $1(2 \%)$ & $0(0 \%)$ & 65 \\
\hline \multirow{6}{*}{ III } & And & 82 & 34 & 10 & 3 & 1 & 130 \\
\hline & Ann & 31 & 22 & 1 & 4 & - & 58 \\
\hline & Han & 1 & 1 & - & - & - & 2 \\
\hline & Leo & 5 & 3 & 2 & 2 & - & 12 \\
\hline & Mat & 6 & 16 & - & 1 & - & 23 \\
\hline & Total & $125(56 \%)$ & $76(34 \%)$ & $13(6 \%)$ & $10(4 \%)$ & $1(<1 \%)$ & 225 \\
\hline \multirow{7}{*}{ IV } & Ann & 42 & 43 & 6 & 16 & - & 107 \\
\hline & Car & 64 & 135 & 21 & 15 & 1 & 236 \\
\hline & Han & 20 & 29 & 1 & 4 & - & 54 \\
\hline & Leo & 83 & 83 & 6 & 4 & 3 & 179 \\
\hline & Mat & 34 & 53 & 9 & 8 & 1 & 105 \\
\hline & Sve & 275 & 227 & 7 & 34 & 1 & 544 \\
\hline & Total & $518(42 \%)$ & $570(47 \%)$ & $50(4 \%)$ & $81(7 \%)$ & $6(<1 \% \%)$ & 1225 \\
\hline \multicolumn{2}{|c|}{ Total } & $721(46 \%)$ & $683(43 \%)$ & $68(4 \%)$ & $92(6 \%)$ & $7(<1 \%)$ & 1571 \\
\hline
\end{tabular}

\subsection{Summary}

Our analysis of predicative possessive constructions in the German child data has led to the following generalizations:

- HAVE-constructions appear before BELONG-constructions.

- As soon as children start to use HAVE- and BELONG-constructions, they seem to be sensitive to the different definiteness constraints for these constructions: they only use gehören 'belong' with a definite PM, but combine haben 'have' with both definite and indefinite phrases. 
- While HAVE-constructions show target-like mappings of arguments onto grammatical roles, systematic overgeneralizations of the HAVEpattern to the BELONG-verb gehören are observed.

- When gehören emerges, it is initially restricted to its locative use (This belongs here). Moreover, sein 'be' is initially mostly used for predication and location, though the possessive use of this verb precedes the use of gehören.

- Combinations of haben and and sein with adnominal possessive constructions ( $X$ has Y's $Z$, Y's $Z$ is $X$ ) only appear in data from late stage III and stage IV.

Similar to the empirical generalisations about adnominal possessive constructions, these generalisations suggest that children become sensitive to the constraints of their target language very early on. Thus, they are also in line with the emerging consensus about early adaptation to the target language. Moreover, just as in the adnominal domain, we observe an incremental extension of forms and functions. In the case of predicative possessive constructions, we can observe a primacy of locative relations, which is in line with some of the typological literature on possession (see e.g. Baron, Herslund, and Sørensen 2001). Such an incremental developmental path can be captured straightforwardly in lexical learning and usage-based approaches as they explicitly predict that possessive constructions are acquired incrementally. By contrast, full-competence approaches would need to make additional assumptions to account for these observations.

Our findings about the acquisition of predicative possessive constructions cannot only contribute to acquisition research; they can also help us evaluate claims made in theoretical linguistics. In particular, the early and error-free acquisition of HAVE constructions and the observed overgeneralisaton of the HAVE-pattern to the BELONG-verb gehören support the assumption that the HAVE-construction is the unmarked construction. This is in line with a common view in the typological literature on possession (see Baron, Herslund, and Sørensen 2001 for discussion), but it is incompatible with Pinker's earlier analysis.

Recall that the observation that combinations of haben 'have' and sein 'be' with adnominal possessive constructions ( $X$ has $Y$ 's $Z$, Y's $Z$ is $X$ ) appear comparatively cannot be simply attributed to the required sentence length. Note that some of the utterances of this type actually only consist of 4 or 5 words, which is an utterance length that can be observed quite frequently in stages I and II. As we argued above, the combination of different types of possessive relations (temporary physical control vs. long-term 
ownership) might be the reason for the late acquisition of combinations of adnominal possessive constructions with haben. The observation that adnominal possessive constructions also appear late in combination with sein, could suggest a more general explanation: both the sein and the haben constructions that appear late involve adnominal possessive constructions that encode a presupposition about possession, which is then combined with another predication. We will further explore this idea below, where we discuss constructions that encode both possessive relations and Agent-Patient relations.

\section{External possession}

In this section we focus on constructions that involve both possessive relations and Agent-Patient relations. This can be achieved by realizing the possessive relation within a noun phrase and encoding the Agent-Patient relation at the sentential level. For instance, in Jack tapped Frank's shoulder, there is a possessive relationship between Frank and his shoulder, which is captured within the adnominal possessive construction. In addition, there is an Agent-Patient relation between Jack on the one side and Frank and his body part on the other. This relation is mapped onto the subject-object relation. Alternatively, the PR can be realized as an independent verb argument in a so-called EPC (Neumann 1995; Payne and Barshi 1999; Shibatani 1994). For example, in the sentence I tapped Frank on the shoulder; the PR Frank and its PM shoulder are realized as independent phrases. In what follows, we focus on the realisation of possessive relations and Agent-Patient relations in EPCs or adnominal possessive constructions in German and Japanese child language data.

\subsection{External possession in the adult language}

EPCs are very common in German and occur in everyday language addressed to young children (see Neumann 1995; Appendix A, A23). Here, the PR is typically realized as a dative-marked "extra" argument that is not subcategorized by the verb. This extra dative argument refers to the PR of the entity that is the Patient of the Action, while this PM is encoded as the direct accusative object (die Haare 'the hair'). This possessive relation makes it possible that the dative noun phrase is integrated into the construction as an argument with all the morpho-syntactic characteristics of a sub- 
categorised indirect object. The dative PR can be combined with a large variety of intransitive and transitive verbs, but not with verbs that already have a dative argument; see e.g.:

(31) a. Das Zebra beißt dem Hasen in den Schwanz the zebra bites the-DAT hare- into the tail 'The zebra bites the hare's tail'

b. Der Mann waescht dem Baeren die Pfote the man washes the-DAT bear the-ACC paw 'The man washes the bear's paw'

c. Der Junge legt dem Affen den Hut auf den Ruecken the boy puts the-DAT monkey the-ACC hat on the back 'The boy puts the hat on the monkey's back'

d. *Der Junge gibt dem Vater dem Kind das Buch the boy gives the-DAT father the-DAT child the-ACC book' 'The boy gives the child's father the book'

The dative PRs in these constructions are not adjuncts with a semantic case that is solely determined by their thematic role and unaffected by any syntactic processes. Rather, we observe the same syntactically determined case alternations for dative PRs (as in (32)) as for indirect dative objects of three-place verbs (as in (33)). In so-called recipient passive sentences with the auxiliary kriegen/bekommen 'get/become' (e.g. (32b, 33b)), the dative noun phrase of the corresponding active sentence (e.g. (32a, 33a)) carries a nominative marker:

a. Der Mann wäscht dem Hund den Kopf. the-NOM man washes the-DAT dog the-ACC head 'The man washes the dog's head.'

b. Der Hund kriegt den Kopf gewaschen the-NOM dog gets the-ACC head washed 'The dog gets its head washed.'

(33) a. Der Mann gibt dem Baeren den Honig. the-NOM man gives the-DAT bear the-ACC honey 'The man gives the bear the honey.'

b. Der Baer kriegt den Honig gegeben the-NOM bear gets the-ACC honey given 'The bear is given the honey.' 
Thus dative PRs behave differently from dative adjuncts with semantic case, e.g. the so-called ethical datives in (34), which express the attitude the referent of this noun phrase has to the action encoded in the verb. In contrast to dative PRs, ethical dative adjuncts do not exhibit any case alternation in recipient passives. That is, the ethical dative pronouns keep their dative marking, as in $(34 \mathrm{~b}, 35 \mathrm{~b})$ while external PRs appear with nominative marking in recipient passives, as in (35b) - just as indirect dative objects, as in (34b). Moreover, ethical datives can be combined with both indirect objects, as in (34), and dative PRs, as in (35), which suggests that they occupy a different syntactic position, while indirect objects and dative PRs have the same status.

(34) a. Dass $d u \quad$ mir der-DAT Oma that you-NOM me-DAT the-DAT granny nicht wieder die falschen Tabletten gibst! not again the-ACC wrong-ACC tablets give! 'I hope that you won't give granny the wrong tablets again!'

b. Dass mir die Oma nicht wieder that me-DAT the-NOM granny not again die falschen Tabletten gegeben kriegt! the-ACC wrong-ACC tablets given gets! 'I hope that granny won't be given the wrong tablets again!'

(35) a. Dass $d u \quad$ mir nicht wieder that you-NOM me-DAT not again jemandem auf die Füße trittst! someone-DAT on the feet step! 'I hope that you won't step on someone's feet again!'

b. Dass mir nicht wieder jemand that me-DAT not again someone-NOM auf die Füße getreten kriegt! on the feet step gets! 'I hope that nobody gets stepped on their feet again!'

While German exhibits external PR constructions with dative PRs as in (36a), it is also possible to realize the possessive relation within an adnominal possessive construction and the Agent-Patient relation at the sentential level as in (36b): 
(36) a. Sue legt dem Pferd den Sattel auf den Ruecken. Sue lays the-DAT horse the-ACC saddle on the back. 'Sue puts the saddle on the horse's back.'

b. Sue legt den Sattel auf den Ruecken von dem Pferd. Sue lays the-ACC saddle on the back of the horse 'Sue puts the saddle on the horse's back.'

Which of these constructions is selected is determined by semantic factors (see e.g. Neumann 1995; Payne and Barshi 1999). For instance, the PR in EPCs must be perceived as beneficially/adversely affected by an action by virtue of being the PR of the entity which is directly affected by this action. Moreover, the stronger the effect on the PR and the more intimate the possession relation is, the more likely it is that the PR will be encoded as an extra argument. Thus the inalienable possession relation between a person and a body part is more likely to be encoded in an EPC than the relation between a person and an alienable possession (e.g. a car).

While German shows parallels between indirect dative objects and external dative PRs, the presence of indirect dative objects and other dative arguments (e.g. Experiencers) in a language does not imply that this language will also exhibit dative-marked external PRs. For instance, Japanese has indirect dative experiencers and a range of dative constructions that are very similar to German. It also has "double subject" and "double object" EPCs (Tsunoda 1995). However, Japanese lacks external dative PRs. In the translation equivalents of the German examples (31a-c), both PM and PR have to be encoded within the same noun phrase (e.g. Watashi-wa kuma-no te-o aratta '(I) the bear's the paw washed'). Note that the presence of such an IPC does not rule out external PRs per se as EPCs and IPCs can co-exist in languages such as German. Thus, if Japanese children ever started to use datives for external PRs, it would be difficult to overcome this deviation from the target language without recourse to reliable negative evidence.

\subsection{External possession in child language}

As far as we are aware, there are no systematic studies of EPCs in child language. We will therefore first look at our German corpus data and then present some preliminary resuls from elicitation games with German and Japanese children. In our German data, we searched for all utterances that involved an Agent-Patient relationship where the PR of the Patient was 
mentioned: (i) as an extra argument, (ii) within the same noun phrase as the Patient or (iii) both. Table 6 provides an overview.

Table 6. External and adnominal possessive constructions

\begin{tabular}{|c|c|c|c|c|c|c|c|c|c|c|c|c|c|}
\hline & & \multicolumn{4}{|c|}{ Ownership } & \multicolumn{4}{|c|}{ Body-Part } & \multicolumn{4}{|c|}{ Total } \\
\hline & & 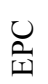 & $\stackrel{\bigcup}{\varrho}$ & 苛 & 豞 & 导 & @ & 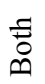 & 䒿 & 足 & $\stackrel{\bigcup}{\varrho}$ & 苛 & 完 \\
\hline \multirow{6}{*}{ III } & And & - & 2 & - & 2 & - & 2 & - & 2 & - & 4 & - & 4 \\
\hline & Ann & - & - & - & - & - & - & - & - & - & - & - & - \\
\hline & Han & - & - & - & - & - & - & - & - & - & - & - & - \\
\hline & Leo & - & - & - & - & - & - & - & - & - & - & - & - \\
\hline & Mat & - & - & - & - & - & - & - & - & - & - & - & - \\
\hline & Total & - & 2 & - & 2 & - & 2 & - & 2 & - & 4 & - & 4 \\
\hline \multirow{7}{*}{ IV } & Ann & - & 2 & - & 2 & - & 1 & - & 1 & - & 3 & - & 3 \\
\hline & Car & 1 & 12 & - & 13 & - & 4 & 1 & 5 & 1 & 16 & 1 & 18 \\
\hline & Han & - & - & - & - & - & - & - & - & - & - & - & - \\
\hline & Leo & - & 2 & - & 2 & 1 & 1 & - & 2 & 1 & 3 & - & 4 \\
\hline & Mat & - & 5 & - & 5 & - & - & - & - & - & 5 & - & 5 \\
\hline & Sve & - & 13 & 1 & 14 & 1 & 1 & & 2 & 1 & 14 & 1 & 16 \\
\hline & Total & 1 & 34 & 1 & 36 & 2 & 7 & 1 & 10 & 3 & 41 & 2 & 46 \\
\hline \multicolumn{2}{|c|}{ Total } & 1 & 36 & 1 & 38 & 2 & 9 & 1 & 12 & 3 & 45 & 2 & 50 \\
\hline
\end{tabular}

As indicated in Table 6, Hannah does not produce any combinations of possessive relations and Agent-Patient relations. For the other children, such combinations only appear in stage III (Andreas) or IV (for the other children; see the examples below) - i.e. at the same time when we can observe the first combinations of haben 'have' and adnominal possessive constructions (see the previous section) and the first combinations of adnominal possessive constructions with a further prediction introduced by sein 'be'. This is in line with our idea that the combination of possessive relations and other relations is a later development. Again, the fact that combinations of possessive relations with another relation appear compartiavely late cannot simply be attributed to sentence length as four or five words would be sufficient for such constructions.

Moreover, EPCs are very rare in our child data. We only found three examples; see e.g. (37). Children tend to use constructions where possessive relations are encoded within a noun-phrase - even when most adults would probably prefer an EPC to encode events of taking something away from someone, grooming and getting dressed, see e.g. (38). This suggests that the 
integration of both possessive and Agent-Patient relations into one single representation for verb arguments poses particular problems. This is supported by the fact that we also found two utterances where the PR appeared both as a pronominal dative argument (mir 'to-me') and as a pronominal possessive pronoun (meine 'my') - as if the occurrence of the extra dative argument was insufficient to encode both the fact that the PR is affected by the action and the fact that the speaker is the PR of the shoes/hands.

(37) jetz hau ich dir aber aber ganz xxx den popo. now hit I you-DAT PART PART really xxx the-ACC botty. 'Now I will really hit you on the botty.'

(Svenja/15/3;2)

(38) a. mama hat meine hose weggemommt (=weggenommen) mommy has my trousers away-taken. 'Mommy has taken away my trousers.'

(Annelie/05/2;8)

b. jetzzieh i(ch) wieder mein(e) schuhe an. now put Iagain my shoes on.

(Svenja/14/3;2) 'Now I am putting on my shoes again.'

(39) a. mama du solls(t) mir jetz meine hände aber waschen. mommy you shall me-DAT now my hands PART wash. 'Mommy, you ought to wash my hands now.'

(Carsten/3;6)

b. dann dann zieh ich mir

then then put I me-DAT

$($ Svenja/10/3;1)

meine meine schusche (=schuhe) an.

my my shoes on.

'Then I will put on my shoes.'

Clearly, further studies of external possession with older children are necessary. Moreover, in order to raise the number of potential contexts for external possession contexts, elicitation stimuli or games might be needed (see e.g. the picture book stimulus by Eisenbeiß and McGregor 1999).

We have obtained some preliminary evidence from an elicitation study with Japanese and 20 German and Japanese children (2-6 yrs; Eisenbeiß and Matsuo 2003, 2005). This study made use of the puzzle tasks where children are asked to describe events depicted on a puzzle board to obtain puzzle pieces with matching pictures. The individual pictures on the puzzle board differ minimally from each other, so that children have to express the differences verbally in order to clearly identify the puzzle piece they want. For the external possession study, three different types of events with af- 
fected body parts were depicted and the pictures differed with respect to the participants and body-parts, see Figure 1.
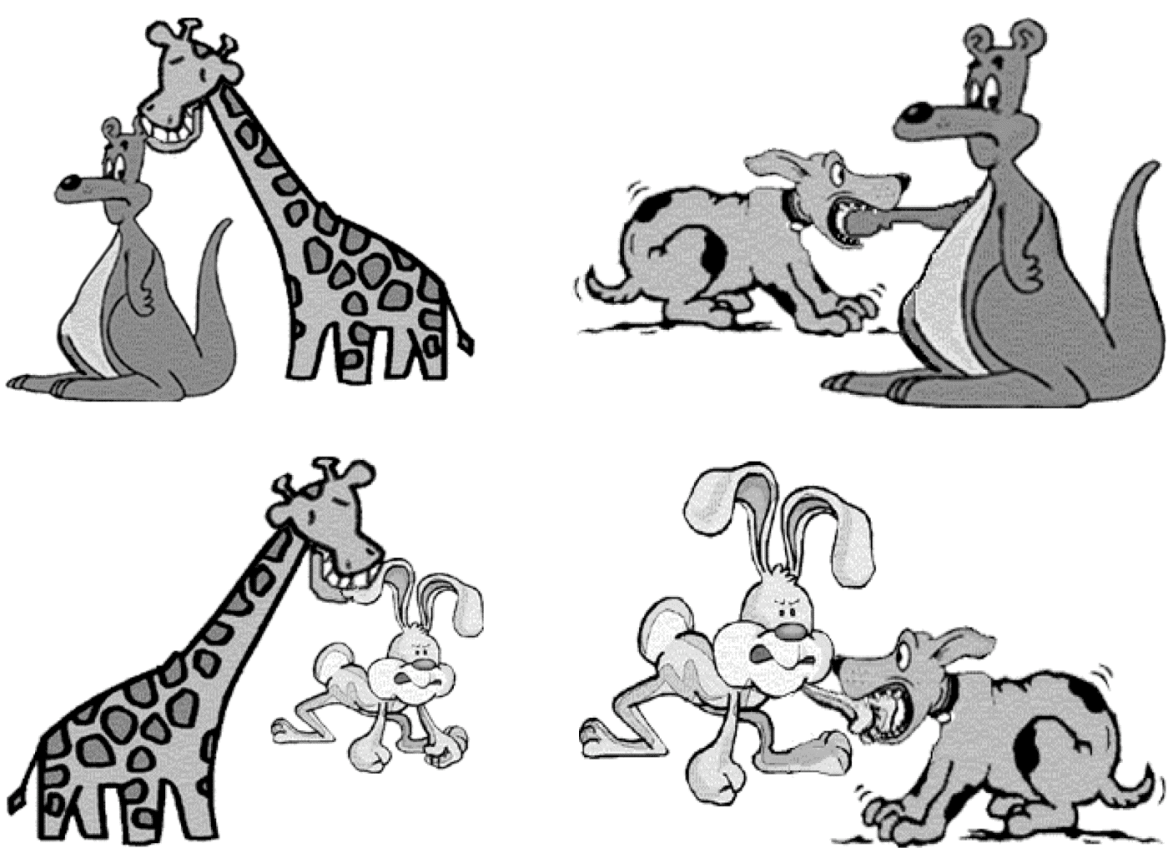

Figure 1. Sample elicitation materials for External Possessive Constructions (Eisenbeiß and Matsuo 2003, 2005)

In order to obtain the desired puzzle piece, children had to mention Agents, Patients and those body parts that were affected by the action. The German target sentences with a dative PR involved three different constructions, one with a nominative subject and a prepositional phrase for the body part as in (40), one with a nominative subject and a direct accusative object as in (41), and one with a subject, a direct accusative object and a prepositional phrase for the body part as in (42).

(40) Das Zebra beißt dem Hasen in den Schwanz the zebra bites the-DAT hare into the tail 'The zebra bites the hare's tail.'

(41) Der Mann waescht dem Hund den Schwanz the man washes the-DAT dog the-ACC tail 'The man washes the dog's tail.' 
(42) Der Junge legt dem Pferd den Sattel auf den Ruecken the boy puts the-DAT horse the-ACC saddle on the back 'The boy puts the saddle on the horse's back.'

An initial analysis of the data showed early adaptations to the target language: Japanese children consistently realized the possessive relationship noun-phrase-internally, whereas German children used EPCs in more than $80 \%$ of the utterances that referred to a body part and its PR. However, many utterances produced in the elicitation game were not target-like. When children produced adnominal possessive constructions instead of external PR constructions (which are not strictly ungrammatical, just dispreferred), they sometimes exhibited the $-s$ overgeneralizations to single PR nouns that we described above, leading to non-target-like utterances such as (43).

When they attempted to produce external PR constructions, children often do not manage to realize the PR as a case-marked dative noun phrase, but use a prepositional phrase instead, as in (44). Note that these utterances are not always target-like. If they use the preposition von 'of' for the PR, they should use it within an adnominal possessive construction, following the PM. Instead, they sometimes position the von-phrase to the left of the PM, sometimes with other elements in between. This leads to utterances that are not acceptable for the adult speakers we consulted, as in the case of $(44 a, b)$. We also found utterances where the child used two prepositional phrases with directional prepositions - one for the body part and one for its PR, as in (44c). Thus, both were mentioned as the endpoint of the caused motion event, but in a parallel fashion. This is also not an option in adult German.

Note that the deviations from the target we observed in the elicitation games do not seem to be an artifact of the elicitation technique. Recall that we found $-s$ overgeneralizations and fronted prepositional phrases for PRs in different sets of corpus data. We will argue that the deviations from the target in these utterances result from difficulties in the intergration of possessive and Agent-Patient relations. This is supported by the observation that they were more likely to use adult-like external possessive constructions for two-place verbs such as bite than for three-place verbs such as put.

(43) a. Da legt der junge die leine auf katzes hals there puts the boy the-ACC leash on cat's neck 'There the boy puts the leash around the cat's neck.'

b. Da legt der junge den hut auf affens bauch there puts the boy the-ACC hat on monkey's tummy 'There the boy puts the hat on the monkey's tummy.' 
(44) a. $d a \quad v[/]$ legt der junge vom pferd auf'n ruecken there $[/]$ puts the boy of:the horse on:the back

den sattel

the-ACC saddle

'There the boy put the saddle on the back of the horse.'

b. von kuh der junge in den (corr: das) bein beissen of cow the boy into the-ACC.MASC (corr:NEUT) leg bite 'The boy bites the cow's leg.'

c. da legt der junge auf den pferd auf den kopf there puts the-NOM boy on the horse on the head

den sattel.

the-ACC saddle.

'There, the boy puts the saddle on the horse's back.'

\subsection{Summary}

Clearly, more studies are required for EPCs. However, our analysis of predicative possessive constructions in the German child data has led to some preliminary generalizations and insights:

- In spontaneous speech from German children, we did not observe any EPCs in stages I-III and only a few examples in stage IV.

- The German children from our corpus study sometimes produced constructions where possessive relations are encoded within a noun-phrase even when most adults would probably prefer an EPC to encode events of taking something away from someone, grooming and getting dressed. The older children in our elicitation study preferred EPCs to adnominal possessive constructions for events where the body part of an animate PR is affected physically, but also sometimes chose to realize the possessive relation noun-phrase internally where an adult would produce an extra dative PR.

- We found a few external possessive constructions where the PR was realized both as a dative argument and as a possessive pronoun within the possessum noun phrase.

- External PR constructions contained more deviations from the targetlanguage for three-place verbs like legen 'put' than for two-place verbs like beissen 'bite'. 
- Common error types were the use of prepositional PR phrases instead of dative PRs; and some of these prepositional phrases were fronted, which is highly marked (or even non-target-like for many native speakers).

- By contrast, Japanese children do not overextend the use of the datives they hear in their input to produce EPCs with dative PRs, which they do not encounter in their target language.

Taken together, these observations suggest children adapt to the properties of their target language quite early, but the integration of both possessive and Agent-Patient relations into one single representation for verb arguments poses problems. Moreover, we found additional evidence for a tendency to position the PR before the PM - even if this leads to non-targetlike utterances.

\section{Implications for theoretical linguistics and models of language acquisition}

When we compare the results for adnominal, predicative and external possessive constructions, we observe incremental development in all three domains: the constructions of the target language emerge step by step. At the same time, the range of functions that are encoded by possessive constructions increases over time. For adnominal possessive constructions, the range of relations expands from prototypical possessive relations via body part relations to relationships between objects and their parts. In the case of predicative possessive constructions, we can observe a primacy of locative relations in early stages, which is in line with the typological literature on possession.

In addition to incremental development, we found initial lexical restrictions for both possessive -s-markers and possessive pronouns in adnominal possessive constructions. As discussed above, both incremental development and initial lexical restrictions are explicitly predicted by structurebuilding approaches as well as usage-based approaches. By contrast, capturing such a developmental path would require additional assumptions in a full-competence approach, for instance, reference to the interaction between linguistic development and the learning of cultural norms for possessive relations and negotiations about them.

While children may not use the full range of forms and functions in the early two-word stage, they seem to adapt to the core properties of their target language early on. For instance, children overgeneralise the German $-s$ - 
marker, which is restricted to unmodified proper names and kinship terms, to count nouns that cannot be used in this way. However, they do not overgeneralise $-s$ to modified nouns. Thus, they respect the syntactic constraint of the adult language and do not adopt the incorrect generalization that $-s$ can be affixed to any names or kinship terms, whether they are modified or not. We have argued that children do not make the non-target-like semantic generalization because they would need positive evidence to assume that $-s$ can also be combined with more complex noun phrases - and they do not find any such evidence in their input. In particular, we suggested that this could be captured in feature-based underspecification models of morphosyntactic development - such as the one proposed by Eisenbeiß (2003; see Eisenbeiß 2007, 2009 for summaries). In such a model, the difference between a simple noun and a complex noun phrase could be captured by additional features for phrasal projections and children would only include such a phrase-feature in their input specification for $-s$ if they find positive evidence for it in their input - as they do in English - but not in a language like German.

We also observed some overgeneralisations of the HAVE-pattern of mapping arguments onto grammatical functions to BELONG-verbs. This is surprising if one assumes that the BELONG-pattern is a "canonical" pattern, as the analysis by Pinker (1984) suggests. However, if one assumes that the HAVE-pattern is the default pattern (see Baron, Herslund and Sørensen 2001 for discussion), such overgeneralisations are to be expected. However, further cross-linguistic research is required to determine whether children ever produce the reverse overgeneralisations and whether these overgeneralisations could simply be attributed to the high frequency of the HAVE-pattern. Similarly, we would like to see more studies of the acquisition of word order in possession constructions to determine whether the observed tendency to position the PR before the PM is a more general phenomenon.

BELONG-constructions and $\mathrm{PM}<\mathrm{PR}$-orders were not the only areas of difficulty that we identified. In particular, we observed that children initially did not use constructions that combine possessive relations with other possessive or non-possessive relations: combinations of haben 'have' and sein 'be' with adnominal possessive constructions ( $X$ has Y's Z, Y's $Z$ is $X$ ) and EPCs that integrate Agent-Patient relations into one single representation for verb arguments. However, in order to evaluate how general this observation is, we would need more cross-linguistic studies of the encoding of possession, in particular for predicative and external possessive constructions. 


\section{Appendix A: A family discussion of possession}

(A1) Mother: du isst noch dein eis?

you eat still your ice-cream?

'You are still eating your ice-cream?'

(A2) Liam: issn [?] ich noch mein eis.

eat I still my ice-cream

'I am still eating my ice-cream'

(A3) Mother: ja, iss mal schoen weiter.

yes eat PART nicely further.

'Yes, just go on eating'

(A4) Mother: lass dir ruhig zeit.

leave yourself quietly time

'Give yourself some time'

(A5) Mother: womit isst du das eis denn?

what-with eat you the icecream PART?

'With what are you eating the icecream?'

(A6) Liam: $\quad x x x$ mit Ole, $h m$ mit Leon, mit $x x x$. with Ole, hm with Leon, with $\mathrm{xxx}$

'With Ole, hm with Leon, with xxx.'

(A7) Mother: aha.

$\mathrm{Ah}$

'Ah'

(A8) Mother: womit [?].

what-with

'With what?'

(A9) Liam: mit $d u \quad$ [?] (=dir)

with you-NOM (corr: DAT)

'With you.'

(A10) Mother: womit [?] $d u$ [?] und isst du das [//]

what-with [?] du [?] and eat you that

ist das dein messer,

is that your knife

oder womit isst du das?

or what-with eat you that?

'With what [?] you [?] and you eat that [//] is that your

knife or with what are you eating that?' 
(A11) Liam: mein loeffel.

my spoon

'My spoon.'

(A12) Mother: das is(t) dein loeffel?

that is your spoon

'That is your spoon?

(A13) Liam: $j a$.

yes

'Yes.'

(A14) Mother: nein, das is(t) mamas loeffel.

no, that is mommy's spoon

'No, that is mommy's spoon.'

(A15) Liam: $n a$.

na

'No.'

(A16) Mother: aber mamas eis.

but mommy's ice-cream

'but (it is) mommy's ice-cream.'

(A17) Liam: $n a$.

na

'No.'

(A18) Mother: mir gehoert das eis.

me-DAT belongs the ice-cream

'The ice-cream belongs to me.'

(A19) Liam: nea.

nea

'No.'

(A20) Mother: ach dir gehoert das eis.

oh you-DAT belongs the-NOM ice-cream.

'oh, the ice-cream belongs to you.'

(A20) Mother: na gut, dann is(t) gut.

oh well, then is good

'That is ok, then.'

(A21) Mother: oder gehoert das der Luna?

or belongs that the-DAT Luna?

'Or does it belong to Luna?' 
(A22) Lenny: der Leon hat sich nich(t) die zaehne the Leon has himself not the-ACC teeth geputzt, mama. brushed, mommy

'Leon has not brushed his teeth, mommy.'

(A23) Mother: Leon, putz dir bitte die zaehne, ja? Leon, brush you-DAT please the teeth, yes? 'Leon, brush your teeth, yes?'

This transcript comes from the L-family corpus, a corpus collected by Sonja Eisenbeiß (http://corpus1.mpi.nl/ds/imdi_browser/, see MPI corpora > L1 Acquisition). The collection and archiving of this corpus has been funded by the Max-Planck-Society; and we would like to thank the family for their participation in the project and all the members of the Max-PlanckInstitute who were involved in the collection, digitization and archiving of the data. The transcription of the recordings was funded by a Research Promotion Grant of the University of Essex, awarded to Sonja Eisenbeiß. The video recordings were transcribed by two native speakers and conflicts were either resolved or - if this was not possible - the relevant (part of the) utterance was classified as unintelligible (Eisenbeiß and Sonnenstuhl 2007). The ages at the time of recording are: Lenny $(7 ; 9)$, Leon $(4 ; 7)$, Liam $(2 ; 5)$.

\section{Appendix B: Stages of Noun-Phrase Development}

\begin{tabular}{|c|c|c|c|c|c|c|c|c|c|c|c|c|c|}
\hline \multirow[b]{2}{*}{ child } & \multirow[b]{2}{*}{ File $^{\mathrm{a}}$} & \multirow[b]{2}{*}{ age } & \multirow[b]{2}{*}{ MLU } & \multicolumn{2}{|c|}{ utterances } & \multirow[b]{2}{*}{ stage } & \multicolumn{3}{|c|}{ D-contexts } & \multicolumn{2}{|c|}{$\begin{array}{c}\text { predicate } \\
+\mathrm{D}- \\
\text { formula }\end{array}$} & \multicolumn{2}{|c|}{$\begin{array}{c}\text { remaining } \\
\mathrm{D}+\mathrm{N} \\
\text { combinations }\end{array}$} \\
\hline & & & & $\mathrm{n}$ & anal. & & $\mathrm{n}$ & $+\mathrm{D}$ & $\%$ & $\mathrm{n}$ & $\begin{array}{l}\% \text { of } \\
+\mathrm{D}\end{array}$ & tokens & types per file \\
\hline \multirow{4}{*}{ Ann } & $1-2$ & $\begin{array}{l}2 ; 4- \\
2 ; 5\end{array}$ & $\begin{array}{l}2,01- \\
2,11\end{array}$ & 651 & 473 & I & 71 & 33 & 46 & 16 & 48 & 17 & $\# 1: 7, \# 2: 7$ \\
\hline & 3 & $2 ; 6$ & 2,53 & 438 & 340 & II & 83 & 35 & 42 & 5 & 14 & 30 & $\# 3: 25$ \\
\hline & 4 & $2 ; 7$ & 2,61 & 589 & 490 & III & 93 & 70 & 75 & 2 & 3 & 68 & $\# 4: 56$ \\
\hline & $5-6$ & $\begin{array}{l}2 ; 8- \\
2 ; 9\end{array}$ & $\begin{array}{l}2,54- \\
3,07\end{array}$ & 744 & 674 & IV & 133 & 125 & 94 & 9 & 7 & 116 & $\# 5: 37, \# 6: 47$ \\
\hline \multirow{4}{*}{ Han } & $1-2$ & $\begin{array}{l}2 ; 0- \\
2 ; 1\end{array}$ & $\begin{array}{l}1,18 \\
1,23\end{array}$ & 552 & 442 & I & 33 & 19 & 58 & 14 & 74 & 5 & $\# 1: 3, \# 2: 2$ \\
\hline & $3-4$ & $\begin{array}{l}2 ; 2- \\
2 ; 3\end{array}$ & $\begin{array}{l}1,23- \\
1,38\end{array}$ & 499 & 355 & II & 50 & 10 & 20 & 6 & 60 & 1 & $\# 3: 1, \# 4: 3$ \\
\hline & 5 & $2 ; 4$ & 1,65 & 96 & 54 & III & 10 & 7 & 70 & 0 & 0 & 7 & $\# 5: 5$ \\
\hline & $6-8$ & $\begin{array}{l}2 ; 6- \\
2 ; 8\end{array}$ & $\begin{array}{l}2,45- \\
2,85\end{array}$ & 831 & 538 & IV & 136 & 131 & 96 & 0 & 0 & 131 & $\begin{array}{l}\# 6: 23, \# 7: 47, \\
\# 8: 31\end{array}$ \\
\hline
\end{tabular}




\begin{tabular}{|c|c|c|c|c|c|c|c|c|c|c|c|c|c|}
\hline \multirow[b]{2}{*}{ child } & \multirow[b]{2}{*}{ File $^{\mathrm{a}}$} & \multirow[b]{2}{*}{ age } & \multirow[b]{2}{*}{ MLU } & \multicolumn{2}{|c|}{ utterances } & \multirow[b]{2}{*}{ stage } & \multicolumn{3}{|c|}{ D-contexts } & \multicolumn{2}{|c|}{$\begin{array}{c}\text { predicate } \\
+\mathrm{D}- \\
\text { formula }\end{array}$} & \multicolumn{2}{|c|}{$\begin{array}{l}\text { remaining } \\
D+N \\
\text { combinations }\end{array}$} \\
\hline & & & & $\mathrm{n}$ & anal. & & $\mathrm{n}$ & $+\mathrm{D}$ & $\%$ & $\mathrm{n}$ & $\begin{array}{l}\begin{array}{l}\% \text { of } \\
+\mathrm{D}\end{array} \\
\end{array}$ & tokens & types per file \\
\hline \multirow{4}{*}{ Leo } & $1-2$ & $\begin{array}{l}1 ; 11 \\
-2 ; 0\end{array}$ & $\begin{array}{l}1,57- \\
1,67\end{array}$ & 576 & 341 & I & 27 & 12 & 44 & 8 & 67 & 4 & $\# 1: 2, \# 2: 2$ \\
\hline & $3-4$ & $\begin{array}{l}2 ; 1- \\
2 ; 2\end{array}$ & $\begin{array}{l}1,60- \\
1,66\end{array}$ & 659 & 414 & II & 32 & 11 & 34 & 7 & 64 & 4 & $\# 3: 3, \# 4: 1$ \\
\hline & $5-8$ & $\begin{array}{l}2 ; 3- \\
2 ; 5\end{array}$ & $\begin{array}{l}1,86- \\
2,08\end{array}$ & 1587 & 1166 & III & 183 & 131 & 72 & 21 & 16 & 110 & $\begin{array}{l}\text { \#5: 10, \#6: } 26, \\
\# 7: 26, \# 8: 17\end{array}$ \\
\hline & $\begin{array}{l}9- \\
15\end{array}$ & $\begin{array}{l}2 ; 6- \\
2 ; 11\end{array}$ & $\begin{array}{l}2,12- \\
3,06\end{array}$ & 3157 & 2462 & IV & 545 & 499 & 92 & 33 & 7 & 466 & $\begin{array}{l}\# 9: 36, \# 10: 38, \\
\# 11: 58, \# 12: 54, \\
\# 13: 42, \\
\# 14: 47, \# 15: 52\end{array}$ \\
\hline \multirow{4}{*}{ Mat } & $\begin{array}{l}9- \\
17\end{array}$ & $2 ; 3-$ & $\begin{array}{l}1,25- \\
2,11\end{array}$ & 1210 & 901 & I & 178 & 22 & 12 & 0 & 0 & 22 & $\begin{array}{l}\# 9: 0, \# 10: 2, \\
\# 11: 0, \# 12: 0, \\
\# 13: 2, \# 14: 0, \\
\# 15: 3, \# 16: 2, \\
\# 17: 10\end{array}$ \\
\hline & 18 & $2 ; 11$ & 2,62 & 123 & 115 & II & 18 & 4 & 22 & 0 & 0 & 4 & $\# 18: 4$ \\
\hline & $\begin{array}{l}19- \\
21\end{array}$ & $\begin{array}{l}2 ; 11 \\
-3 ; 0\end{array}$ & $\begin{array}{l}2,62- \\
2,65\end{array}$ & 264 & 243 & III & 67 & 58 & 87 & 0 & 0 & 58 & $\begin{array}{l}\# 19: 21, \# 20: \\
\text { n.a., } \# 21: 23\end{array}$ \\
\hline & $\begin{array}{l}22- \\
27\end{array}$ & $\begin{array}{l}3 ; 1- \\
3 ; 6\end{array}$ & $2,24-$ & 804 & 719 & IV & 204 & 184 & 90 & 0 & 0 & 184 & $\begin{array}{l}\# 22: 37, \# 23: \\
6, \# 24: 23, \\
\# 25: 27, \# 26: \\
35, \# 27: 28\end{array}$ \\
\hline $\mathrm{And}^{\mathrm{b}}$ & 1 & 2,1 & 2,44 & 2344 & 1450 & III & & & & & & & \\
\hline $\mathrm{Car}^{\mathrm{b}}$ & 1 & 3,6 & 4,22 & 2314 & 1795 & IV & & & & & & & \\
\hline
\end{tabular}

a The column "file" provides the number of the respective recording. The column MLU shows the mean length of utterance for this recording. The columns under "utterances" provide the total number of utterances and the total number of analyzable utterances (i.e. utterances that were intelligible and not simple yes/no answers or formulas such as hallo 'hello'). Under "D-contexts" are: (i) the number of contexts in which an adult native speaker would have produced a D-element, i.e. a nominal function word (determiner, possessive pronoun or quantifier), (ii) the number of overt D-elements and (iii) the percentage of D-contexts where a D-element was used. The column predicate+D-formula shows how many of the D-elements that children produced were found in potentially formulaic combinations with a small set of high-frequency predicates (e.g. das-is-ein- $X$ 'that-is-a-X', diemama 'the mommy'). The following columns show how many tokens and different types of D-element-noun combinations remained after we excluded the predicate+D formulas from the total number of D-elements in D-contexts.

${ }^{\mathrm{b}}$ For the cross-sectional data from the advanced stages no quantitative analyses of predicate $+\mathrm{D}$ formula and $\mathrm{D}+\mathrm{N}$ combinations were carried out as both Andreas and Carsten used D-elements with broad ranges of nouns and predicates in obligatory contexts. 


\section{Acknowledgements}

We would like to thank the children and the families who provided us with data and Harald Clahsen for letting us use the Lexlern data. We are grateful to Bill McGregor, Martin Henson and Bettina Landgraf for valuable comments on earlier drafts and to Anette Rosenbach and Nikola Koch for many discussions about possessive constructions. The research reported in this article was supported by a grant from the Research Promotion Fund, University of Essex.

\section{References}

Ambridge, Ben, Julian M. Pine, Caroline F. Rowland and Chris R. Young

2008 The effect of verb semantic class and verb frequency (entrenchment) on children's and adults' graded judgments of argument structure overgeneralization errors. Cognition 106: 87-129.

Armon-Lotem, Sharon

1998 Mommy sock in a minimalist eye: On the acquisition of DP in Hebrew. In Issues in the Theory of Language Acquisition, Norbert Dittmar and Zvi Penner (eds.), 15-36. Bern: Lang.

Armon-Lotem Sharon, Stephen Crain and Spyridoula Varlokosta

2005 Interface conditions in child language: a crosslinguistic look at some aspects of possession. Language Acquisition: A Journal of Developmental Linguistics 12 (2): 171-217.

Avrutin, Sergey

1999 Development of the Syntax-Discourse Interface. Dordrecht: Kluwer.

Baker, Carl L.

1979 Syntactic theory and the projection problem. Linguistic Inquiry 10: 533-581.

Baron, Irene, Michael Herslund and Finn Sørensen (ed.)

2001 Dimensions of Possession. Amsterdam/Philadelphia: Benjamins.

Bates, Elizabeth and Brian MacWhinney

1987 Competition, variation and language learning. In Mechanisms of Language Acquisition, Brian MacWhinney (ed.), 157-194. Hillsdale, NJ: Erlbaum.

Berman, Ruth A.

1985 The acquisition of Hebrew. In The Crosslinguistic Study of Language Acquisition. Vol.1, Dan I. Slobin (ed.), 255-371. Hillsdale, NJ: Erlbaum.

1988 Word elass distinetions in developing grammars. In Categories and Processes in Language Aequisition, Yonata Levy, Izchak M. Schlesinger, and Martin D. S. Braine (eds.), 45 72. Hillsdale, NJ: Erlbaum. 
Bertolo, Stefano (ed.)

2001 Language Acquisition and Learnability. Cambridge: Cambridge University Press.

Bohnacker, Ute

1997 Determiner phrases and the debate on functional categories in early child language. Language Acquisition 6: 49-90.

Borer, Hagit and Kenneth Wexler

1987 The maturation of syntax. In Parameter Setting, Thomas Roeper and Edwin Williams (eds.), 123-172. Dordrecht: Reidel.

Bowerman, Melissa

1985 Mapping thematic roles onto syntactic functions: are children helped by innate linking rules? Linguistics 28: 1253-1289.

Braine, Martin D. S. and Patricia J. Brooks

1995 Verb argument structure and the problem of avoiding an overgeneral grammar. In Beyond Names for Things: Young Children's Acquisition of Verbs, Michael Tomasello and Walter E. Merriman (eds.), 352376. Hillsdale, NJ: Erlbaum.

Brown, Roger

1973 A First Language: the Early Stages. London: Allen and Unwin.

Chappell, Hilary and William B. McGregor, (eds.)

1996 The Grammar of Inalienability: A Typological Perspective on Body Part Terms and the Part-Whole Relation. Berlin and New York: Mouton de Gruyter.

Chomsky, Noam

1965 Aspects of the Theory of Syntax. Cambridge, MA: MIT Press.

1981 Lectures on Government and Binding. Dordrecht: Foris.

1995 The Minimalist Program. Cambridge, MA: MIT Press.

2001 Beyond explanatory adequacy. MIT Occasional Papers in Linguistics 20. Cambridge, MA: MIT Press.

Chouinard, M. M. and Eve V. Clark

2003 Adult reformulation of childerrors as negative evidence. Journal of Child Language 30, 637-669.

Clahsen, Harald and Martina Penke

1992 The acquisition of agreement morphology and its syntactic consequences: new evidence on German child language from the SimoneCorpus. In The Acquisition of Verb Placement: Functional Categories and V2 Phenomena in Language Acquisition, Jürgen M. Meisel (ed.), 181-224. Dordrecht: Kluwer.

Clahsen, Harald, Sonja Eisenbeiß and Anne Vainikka

1994 The seeds of structure. A syntactic analysis of the acquisition of case marking. In Language Acquisition Studies in Generative Grammar, Teun Hoekstra and Bonnie D. Schwartz (eds.), 85-118. Amsterdam/ Philadelphia: Benjamins. 
Clahsen, Harald, Anne Vainikka, and Martha Young-Scholten 1990 Lernbarkeitstheorie und Lexikalisches Lernen. Eine kurze Darstellung des LEXLERN-Projekts. Linguistische Berichte 130: 466-477.

Clancy, Patricia M.

1985 The acquisition of Japanese. In The Crosslinguistic Study of Language Acquisition. Vol. 1, Dan I. Slobin (ed.), 373-524. Hillsdale, NJ: Erlbaum.

Clark, Eve V.

1978 Ergativity. In Syntactic Typology: Studies in the Phenomenology of Language, Winfred P. Lehmann (ed.), 329-394. Hassocks, Sussex: Harvester Press.

1985 The acquisition of Romance with special reference to French. In The Crosslinguistic Study of Language Acquisition. Vol. 1, Dan I. Slobin (ed.), 687-782. Hillsdale, NJ: Erlbaum.

1987 The principle of contrast: a constraint on language acquisition. In Mechanisms of Language Acquisition, Brian MacWhinney (ed.), 1-33.

Corina, David P. Hillsdale, NJ: Erlbaum.

1994 The induction of prosodic constraints: implications for phonological theory and mental representation. In The Reality of Linguistic Rules, Susan D. Lima, Roberta L. Corrigan and Gregory K. Iverson (eds.), 115-145. Amsterdam/Philadelphia: Benjamins.

Cowie, F.

1999 What's Within: Nativism Reconsidered. New York: Oxford University Press.

Crain, Stephen

1991 Language acquisition in the absence of experience. Behavioral and Brain Sciences 14: 597-611.

Denison, David, Alan Scott and Kersti Börjars

2008 What's wrong with possessive 's? Presentation at ISLE1, University of Freiburg, 8-11 October 2008.

(Available online at http://llc.stage.manchester.ac.uk/subjects/lel/staff/ david-denison/papers/thefile,143616,en.pdf.)

Eisenbeiß, Sonja

1994 Elizitation von Nominalphrasen und Kasusmarkierungen. In Elizitationsverfahren in der Spracherwerbsforschung: Nominalphrasen, Kasus, Plural, Partizipien. (Arbeiten des Sonderforschungsbereichs 282, Nr. 57), Sonja Eisenbeiß, Susanne Bartke, Helga Weyerts and Harald Clahsen (eds.), 1-38. Düsseldorf: Heinrich-Heine-Universität.

2000 The acquisition of the Determiner Phrase in German child language. In The Acquisition of Syntax: Studies in Comparative Developmental Linguistics, Marc-Ariel Friedemann and Luigi Rizzi (eds.), 26-62. London: Longman. 
2003 Merkmalsgesteuerter Grammatikerwerb. Doctoral dissertation, University of Düsseldorf. (Available online at http://docserv.uniduesseldorf.de/servlets/DerivateServlet/Derivate-3185/1185.pdf.)

2006 Documenting child language. In Language Documentation and Description. Vol. 3, Peter K. Austin (ed.), 106-140. London: SOAS, The Hans Rausing Endangered Languages Project.

2007 The lexical learning hypothesis. Essex Research Reports in Linguistics 54: 1-4. (To appear in: The Cambridge Encyclopedia of the Language Sciences.)

2009 Generative approaches to language learning. Linguistics 47 (2): $273-$ 310.

Eisenbeiß, Sonja and Ayumi Matsuo

2003 External and internal possession - a comparative study of German and Japanese child language. Poster presented at the $28^{\text {th }}$ Annual Boston University Conference on Language Development, Boston University, USA.

2005 Eliciting language production data from young children. Presentation at the $\mathrm{X}^{\text {th }}$ International Congress for the Study of Child Language, Berlin, Germany.

Eisenbeiß, Sonja and William B. McGregor

1999 The circle of dirt. Ms. Max-Planck-Institute for Psycholinguistics, Nijmegen.

Eisenbeiß, Sonja and Ingrid Sonnenstuhl

2007 Transcription conventions for the L-family corpus. Ms. University of Essex.

Goldberg, Adele

1995 Constructions. Chicago: University of Chicago Press.

2006 Constructions at Work: the Nature of Generalization in Language. Oxford: Oxford University Press.

Grimshaw, Jane

1994 Minimal projection and clause structure. In Syntactic Theory and First Language Acquisition: Cross-linguistic Perspectives, Barbara Lust, M. Suner and J. Whitman (eds.), 75-83. Hillsdale, N.J.: Lawrence Erlbaum Associates.

Guasti, Maria Teresa, Anne Christophe, Brit van Ooyen and Marina Nespor

2001 Pre-lexical setting of the head: Complement parameter through prosody. In Approaches to Bootstrapping: Phonological, Lexical, Syntactic and Neurophysiological Aspects of Early Language Acquisition, Vol.1, Jürgen Weissenborn and Barbara Höhle (eds.), 231-248. Amsterdam/Philadelphia: Benjamins.

Harbert, Wayne

2007 The Germanic Languages. Illustrated Edition. Cambridge: Cambridge University Press. 
Heine, Bernd

1997 Possession: Cognitive Sources, Forces, and Grammaticalization. New Hyams, Nina M.

York: Cambridge University Press.

1996 The underspecification of functional categories in early grammar. In Generative Perspectives on Language Acquisition. Empirical Findings, Theoretical Considerations and Crosslinguistic Comparisons, Harald Clahsen (ed.), 91-127. Amsterdam/Philadelphia: Benjamins.

Gerhard Jäger and Annette Rosenbach

2006 The winner takes it all - almost. Cumulativity in grammatical variation. Linguistics 44 (5): 937-971.

Kiparsky, Paul

1982 From cyclic phonology to lexical phonology. In The Structure of Phonological Representations. Part 1, Harry van der Hulst and Norval Smith (eds.), 131-175. Dordrecht: Foris.

König, Ekkehard and Martin Haspelmath

1998 Les constructions à possesseur externe dans les langues d'Europe. In Actance et Valence dans les Langues d'Europe, Jack Feuillet (ed.), 525-606. Berlin and New York: Mouton de Gruyter.

Küntay, Aylin and Dan I. Slobin

1996 Listening to a Turkish mother: some puzzles for acquisition. In Social Interaction, Social Context, and Language, Dan I. Slobin, Julie Gerhardt, Amy Kyratzis and Jiansheng Guo (eds.), 265-286. Mahwah, NJ: Erlbaum.

Lust, Barbara

1994 Functional projection of CP and phrase structure parametrization: an argument for the strong continuity hypothesis. In Syntactic Theory and First Language Acquisition: Cross-Linguistic Perspectives. Vol. 1, Barbara Lust, Margarita Suner and John Whitman (eds.), 85-118. Hillsdale, NJ: Erlbaum.

MacWhinney, Brian

2000 The CHILDES Project: Tools for Analyzing Talk. $3^{\text {rd }}$ Edition. Vol. 2: The Database. Mahwah, NJ: Erlbaum.

Marcus, Gary F.

1993 Negative evidence in language acquisition? Cognition 46: 53-85.

Marcus, Gary F., Steven Pinker, Michael Ullman, Michelle Hollander, John T. Rosen and Fei Xu

1992 Overregularization in language acquisition. Monographs of the Society for Research in Child Development. Vol. 57 (Serial No. 228), 1-165.

Marinis, Theodoros

2002 Acquiring the possessive construction in Modern Greek. In Proceedings of the 1999 GALA Conference, Ingeborg Lasser (ed.), 57-80. Frankfurt: Lang. 
Marinis, Theodoros

2003 The Acquisition of the DP in Modern Greek. Amsterdam/Philadelphia: Benjamins.

Miller, Max

1976 Zur Logik der frühkindlichen Sprachentwicklung. Stuttgart: Klett.

Mills, Anne E.

1985 The acquisition of German. In The Crosslinguistic Study of Language Acquisition. Vol. 1, Dan I. Slobin (ed.), 141-254. Hillsdale, NJ: Erlbaum.

Neumann, Dorothea

1995 The dative and the grammar of body parts in German. In The Grammar of Inalienability: A Typological Perspective on Body Part Terms and the Part-Whole Relation, Hilary Chappell and William B. McGregor (eds.), 745-779. Berlin/New York: Mouton de Gruyter.

Payne, Doris L and Immanuel Barshi (eds.)

1999 External Possession. Amsterdam/Philadelphia: Benjamins.

Penner, Zvi, Manuela Schönenberger and Jürgen Weissenborn

1994 The acquisition of object placement in early German and Swiss German. Linguistics in Potsdam 1: 93-108.

Penner, Zvi and Jürgen Weissenborn

1996 Strong continuity, parameter setting and the trigger hierarchy: On the acquisition of the DP in Bernese Swiss German and High German. In Generative Perspectives on Language Acquisition. Empirical Findings, Theoretical Considerations and Crosslinguistic Comparisons, Harald Clahsen (ed.), 161-200. Amsterdam/Philadelphia: Benjamins.

Peters, Ann M. and Lise Menn

1993 False starts and filler syllables: ways to learn grammatical morphemes. Language 69: 742-777.

Phillips, Colin

1996 Order and structure. PhD thesis, Cambridge, MA: MIT.

Pinker, Steven

1984 Language Learnability and Language Development. Cambridge, MA:

Harvard University Press.

1989 Learnability and Cognition: The Acquisition of Argument Structure. Cambridge, MA: MIT Press.

Radford, Andrew

1990 Syntactic Theory and the Acquisition of English Syntax: The Nature of Early Child Grammars of English. Oxford: Blackwell.

1996 Towards a structure-building model of acquisition. In Generative Perspectives on Language Acquisition. Empirical Findings, Theoretical Considerations and Crosslinguistic Comparisons, Harald Clahsen (ed.), 43-90. Amsterdam/Philadelphia: Benjamins. 
Radford, Andrew and Joseph Galasso

1998 Children's possessive structures: a case study. Essex Research ReRizzi, Luigi ports in Linguistics 19. Essex: University of Essex, 37-45.

1993/94 Some notes on linguistic theory and language development: The case of root infinitives. Language Acquisition 3: 371-393.

2000 Remarks on early null subjects. In The Acquisition of Syntax: Studies in Comparative Developmental Linguistics, Marc-Ariel Friedemann and Luigi Rizzi (eds.), 269-292. London: Longman.

Rosenbach, Anette

2002 Genitive Variation in English: Conceptual Factors in Synchronic and Diachronic Studies (Topics in English Linguistics 42.) Berlin/New York: Mouton de Gruyter.

2003 Aspects of iconicity and economy in the choice between the sgenitive and the of-genitive in English. In Determinants of Grammatical Variation in English, Günter Rohdenburg and Britta Mondorf (eds.), 379-411. (Topics in English Linguistics 43) Berlin/New York: Mouton de Gruyter.

2005 Animacy versus weight as determinants of grammatical variation in English. Language 81: 613-644.

2008 Animacy and grammatical variation - findings from English genitive variation. Lingua 118: 151-171.

Ruff, Claudia

2000 Besitz und Besitzer in der Sprachentwicklung von deutschen und italienischen Kindern. PhD thesis, TU Braunschweig, Biowissenschaften, Psychologie. (Available online at http://deposit.ddb.de/cgibin/dokserv?idn=961129425.)

Scott, Alan, David Denison and Kersti Börjars

2007 Is the English possessive 's truly a right edge phenomenon? Handout of paper presented at The Second International Conference on the Linguistics of Contemporary English (ICLCE2), University of Toulouse-le Mirail, $2^{\text {nd }}$ July 2007.

Seiler, Hansjakob

1983 Possession as an Operational Dimension of Language. Tübingen: Narr.

Shibatani, Masayoshi

1994 An integrational approach to PR raising, ethical datives, and adversative passives. BLS 20: 461-486.

Slobin, Dan I., Melissa Bowerman, Penelope Brown, Sonja Eisenbeiß and Bhuvana Narasimhan

in prep $\overline{\overline{\bar{\gamma}}}$ atting things in places: developmental consequences of linguistic typology. 
Stenzel, Achim

1994 Case assignment and functional categories in bilingual children: Routes of development and implications for linguistic theory. In Bilingual First Language Acquisition: French and German Grammatical Development, Jürgen M. Meisel (ed.), 161-208. Amsterdam/Philadelphia: Benjamins.

Stephany, Ursula

1997 The acquisition of Greek. In The Crosslinguistic Study of Language Acquisition. Volume 4, Dan I. Slobin (ed.), 183-333. Mahwah, NJ: Erlbaum.

1998 A crosslinguistic perspective on the category of nominal number and its acquisition. In Studies in the Acquisition of Number and Diminutive Marking, Steven Gillis (ed.), 1-23. (Antwerp Papers in Linguistics 95) Antwerpen: Universitaire Istelling Antwerpen.

Tomasello, Michael

1998 One child's early talk about possession. In The Linguistics of Giving, John Newman (ed.). Amsterdam/Philadelphia: John Benjamins.

2003 Constructing a Language: A Usage-Based Theory of Language Acquisition. Cambridge, MA: Harvard University Press.

2006 Acquiring linguistic constructions. In Handbook of Child Psychology, D. Kuhn and R. Siegler (eds.), 1-101. New York: Wiley.

Tsunoda, Tasaku

1995 The possession cline in Japanese and other languages. In The Grammar of Inalienability: A Typological Perspective on Body Part Terms and the Part-Whole Relation, Hilary Chappell and William B. McGregor (eds.), 565-630. Berlin/NewYork: Mouton de Gruyter.

van der Linden, E. and A. Blok-Boas

2005 Exploring possession in simultaneous bilingualism: Dutch/French and Dutch/Italian. In EUROSLA Yearbook, S. Foster-Cohen, M. d. P. García-Mayo and J. Cenoz (eds.), 103-135. Amsterdam/Philadelphia: Benjamins.

Wagner, Klaus R.

1985 How much do children say in a day? Journal of Child Language 12: 475-487.

Wexler, Kenneth

1998 Very early parameter setting and the unique checking constraint: a new explanation of the optional infinitive stage. Lingua 106: 23-79. 
